NATIONAL LABORATORY

MANAGED BY UT-BATTELLE

FOR THE DEPARTMENT OF ENERGY

\title{
Nuclear Hydrogen for Peak Electricity Production and Spinning Reserve
}

\author{
C. W. Forsberg \\ Oak Ridge National Laboratory
}

January 2005 


\title{
DOCUMENT AVAILABILITY
}

Reports produced after January 1, 1996, are generally available free via the U.S. Department of Energy (DOE) Information Bridge:

Web site: http://www.osti.gov/bridge

Reports produced before January 1, 1996, may be purchased by members of the public from the following source:

\author{
National Technical Information Service \\ 5285 Port Royal Road \\ Springfield, VA 22161 \\ Telephone: 703-605-6000 (1-800-553-6847) \\ TDD: 703-487-4639 \\ Fax: 703-605-6900 \\ E-mail: info@ntis.fedworld.gov \\ Web site: http://www.ntis.gov/support/ordernowabout.htm
}

Reports are available to DOE employees, DOE contractors, Energy Technology Data Exchange (ETDE) representatives, and International Nuclear Information System (INIS) representatives from the following source:

Office of Scientific and Technical Information

P.O. Box 62

Oak Ridge, TN 37831

Telephone: 865-576-8401

Fax: 865-576-5728

E-mail: reports@adonis.osti.gov

Web site: http://www.osti.gov/contact.html

This report was prepared as an account of work sponsored by an agency of the United States Government. Neither the United States government nor any agency thereof, nor any of their employees, makes any warranty, express or implied, or assumes any legal liability or responsibility for the accuracy, completeness, or usefulness of any information, apparatus, product, or process disclosed, or represents that its use would not infringe privately owned rights. Reference herein to any specific commercial product, process, or service by trade name, trademark, manufacturer, or otherwise, does not necessarily constitute or imply its endorsement, recommendation, or favoring by the United States Government or any agency thereof. The views and opinions of authors expressed herein do not necessarily state or reflect those of the United States Government or any agency thereof. 
ORNL/TM-2004/194

\title{
Nuclear Hydrogen for Peak Electricity Production and Spinning Reserve
}

\author{
C. W. Forsberg
}

Oak Ridge National Laboratory

Date Published: January 2005

The submitted manuscript has been authored by a contractor of the U.S. Government under contract DE-AC05-00OR22725.

Accordingly, the U.S. Government retains a nonexclusive, royalty-free license to publish or reproduce the published form of this contribution, or allow others to do so, for U.S. Government purposes.

Prepared by

OAK RIDGE NATIONAL LABORATORY

Oak Ridge, Tennessee 37831-6285

managed by

UT-BATTELLE, LLC

for the

U.S. DEPARTMENT OF ENERGY

under contract DE-AC05-00OR22725 



\section{CONTENTS}

LIST OF FIGURES

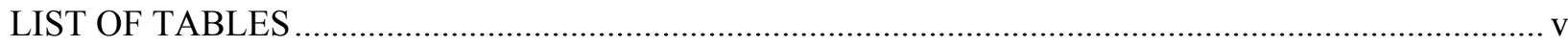

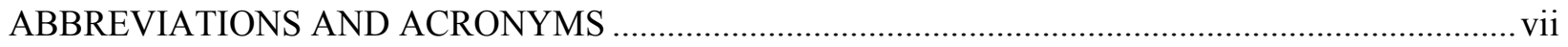

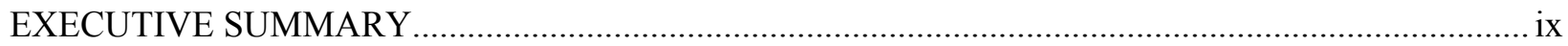

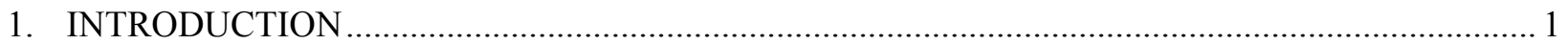

2. THE PEAK-ELECTRICITY NUCLEAR SYSTEM …....................................................... 3

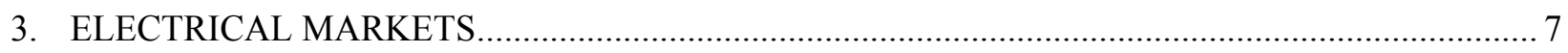

3.1 TIME-OF-DAY VARIATIONS IN ELECTRICITY COSTS...................................

3.1.1 Time-of-Day Pricing and Costs..............................................................

3.1.2 Existing Methods to Meet Peak and Intermediate Power Demands ....................8

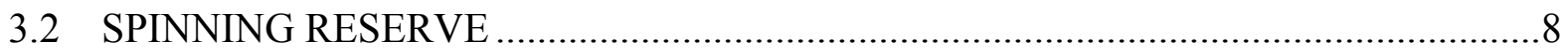

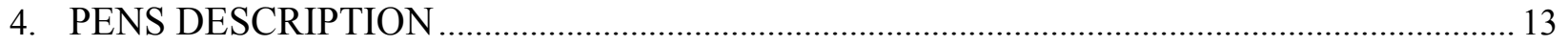

4.1 HYDROGEN PRODUCTION …............................................................................ 13

4.2 HYDROGEN AND OXYGEN STORAGE …............................................................ 14

4.3 FUEL CELLS AND OTHER METHODS FOR INTERMEDIATE AND PEAK

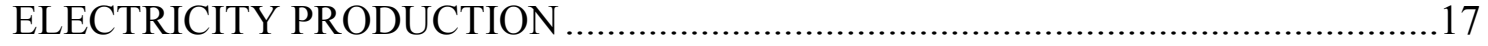

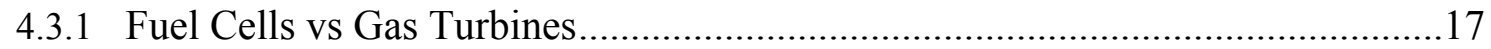

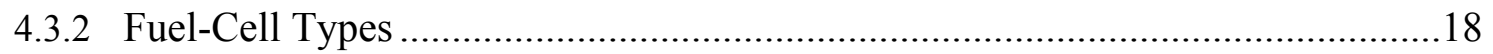

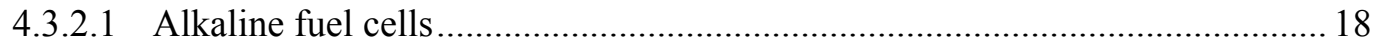

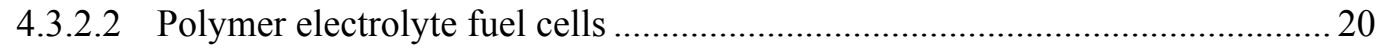

4.3.2.3 Molten carbonate fuel cells....................................................................... 21

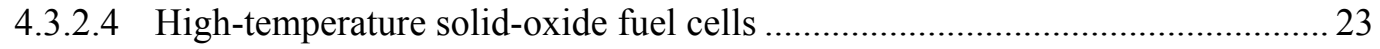

4.3.2.5 Phosphoric acid fuel cells .......................................................................... 24

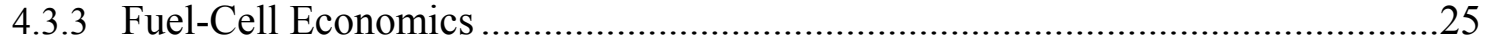

4.4 ELECTRICAL TRANSMISSION ......................................................................26

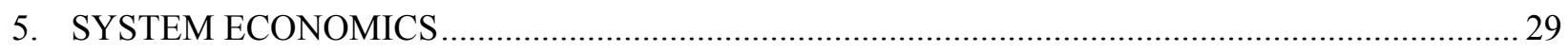




\section{CONTENTS (continued)}

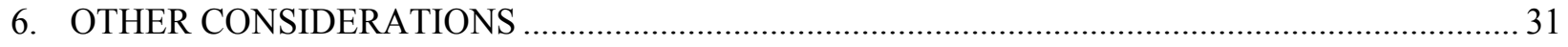

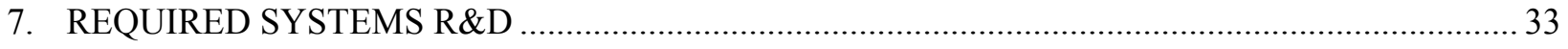

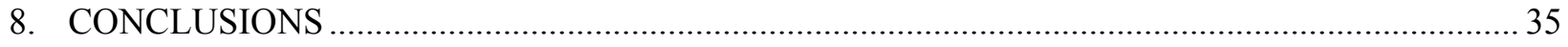

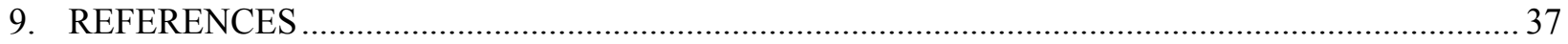




\section{LIST OF FIGURES}

Figure

ES.1 Peak-electricity nuclear system, including relative costs for production....................................ii

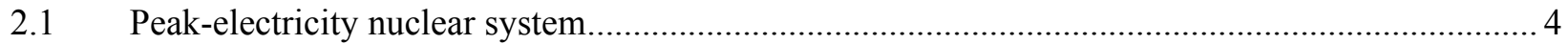

3.1 Price of electricity [ $\$$ MW(e)-h] as a function of time in Alberta, Canada ................................... 7

3.2 Upper water storage and intake structures of the Tennessee Valley Authority Raccoon Mountain

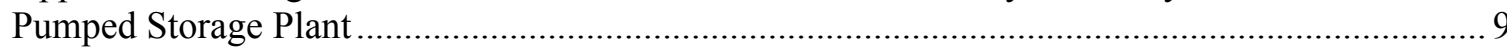

3.3 Underground powerhouse of the Tennessee Valley Authority Raccoon Mountain Pumped

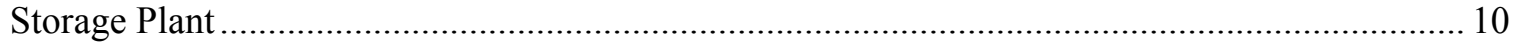

4.1 Technologies for underground storage of compressed gases............................................... 14

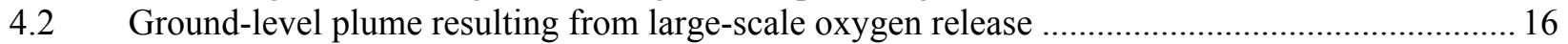

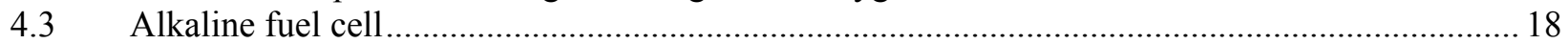

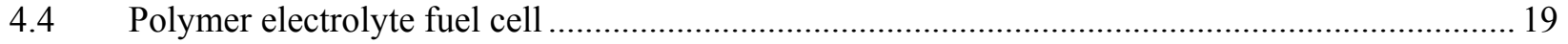

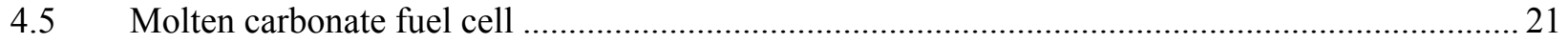

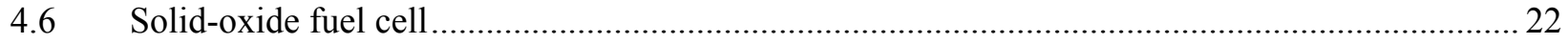

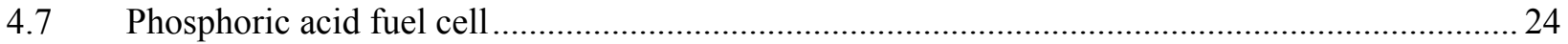

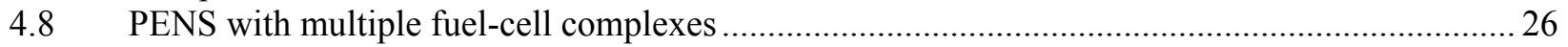

5.1 Relationship of PENS economics to production of electricity for periods of high demand .......... 31

\section{LIST OF TABLES}

Table

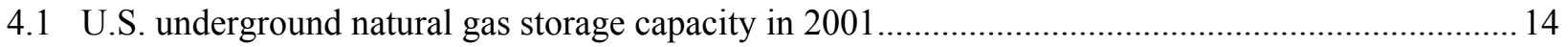

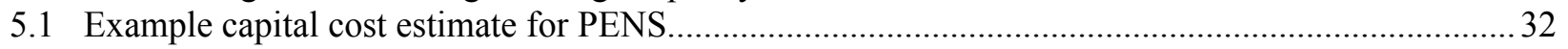




\section{ABBREVIATIONS AND ACRONYMS}

CAES Compressed air energy storage

EPRI Electric Power Research Institute

PENS Peak-electricity nuclear system

RD Research and development

SOFC Solid-oxide fuel cell

TVA Tennessee Valley Authority 


\section{EXECUTIVE SUMMARY}

Nuclear energy can be used to produce hydrogen. The key strategic question is this: "What are the early markets for nuclear hydrogen?" The answer determines (1) whether there are incentives to implement nuclear hydrogen technology today or whether the development of such a technology could be delayed by decades until a hydrogen economy has evolved, (2) the industrial partners required to develop such a technology, and (3) the technological requirements for the hydrogen production system (rate of production, steady-state or variable production, hydrogen purity, etc.). Understanding "early" markets for any new product is difficult because the customer may not even recognize that the product could exist.

This study is an initial examination of how nuclear hydrogen could be used in two interconnected early markets: the production of electricity for peak and intermediate electrical loads and spinning reserve for the electrical grid. The study is intended to provide an initial description that can then be used to consult with potential customers (utilities, the Electric Power Research Institute, etc.) to better determine the potential real-world viability of this early market for nuclear hydrogen and provide the starting point for a more definitive assessment of the concept.

If this set of applications is economically viable, it offers several unique advantages: (1) the market is approximately equivalent in size to the existing nuclear electric enterprise in the United States, (2) the entire market is within the utility industry and does not require development of an external market for hydrogen or a significant hydrogen infrastructure beyond the utility site, (3) the technology and scale match those of nuclear hydrogen production, (4) the market exists today, and (5) the market is sufficient in size to justify development of nuclear hydrogen production techniques independent of the development of any other market for hydrogen. These characteristics make it an ideal early market for nuclear hydrogen.

The demand, cost, and market price for electricity vary daily, weekly, and seasonally. The variability of the price of electricity creates the potential for a large nuclear hydrogen market aimed at producing electricity at those times of day when the price of electricity is at its maximum. A peak-electricity nuclear system (PENS) using nuclear hydrogen consists of three major components (Fig. ES.1):

- Hydrogen production. A nuclear power plant is used to produce hydrogen and oxygen from water at a constant rate using thermochemical or electrolytic processes.

- Hydrogen and oxygen storage. Underground storage facilities are used for the low-cost storage of hydrogen and oxygen. Underground high-pressure gas storage is the traditional approach to the lowcost storage of natural gas to meet variable seasonal demand. The total existing natural gas underground storage capacity in the United States is about 8 trillion cubic feet, a volume far larger than would be required for full deployment of PENS. Underground storage facilities are already used for hydrogen storage in some countries.

- Hydrogen-to-electricity conversion. Large banks of fuel cells are used to convert hydrogen to electricity during periods of higher-priced electricity. For every megawatt of steady-state hydrogen production from the nuclear reactor, the fuel cells would be capable of generating several megawatts of electricity. At times of low electrical demand and price, the fuel cells would produce no electricity. 


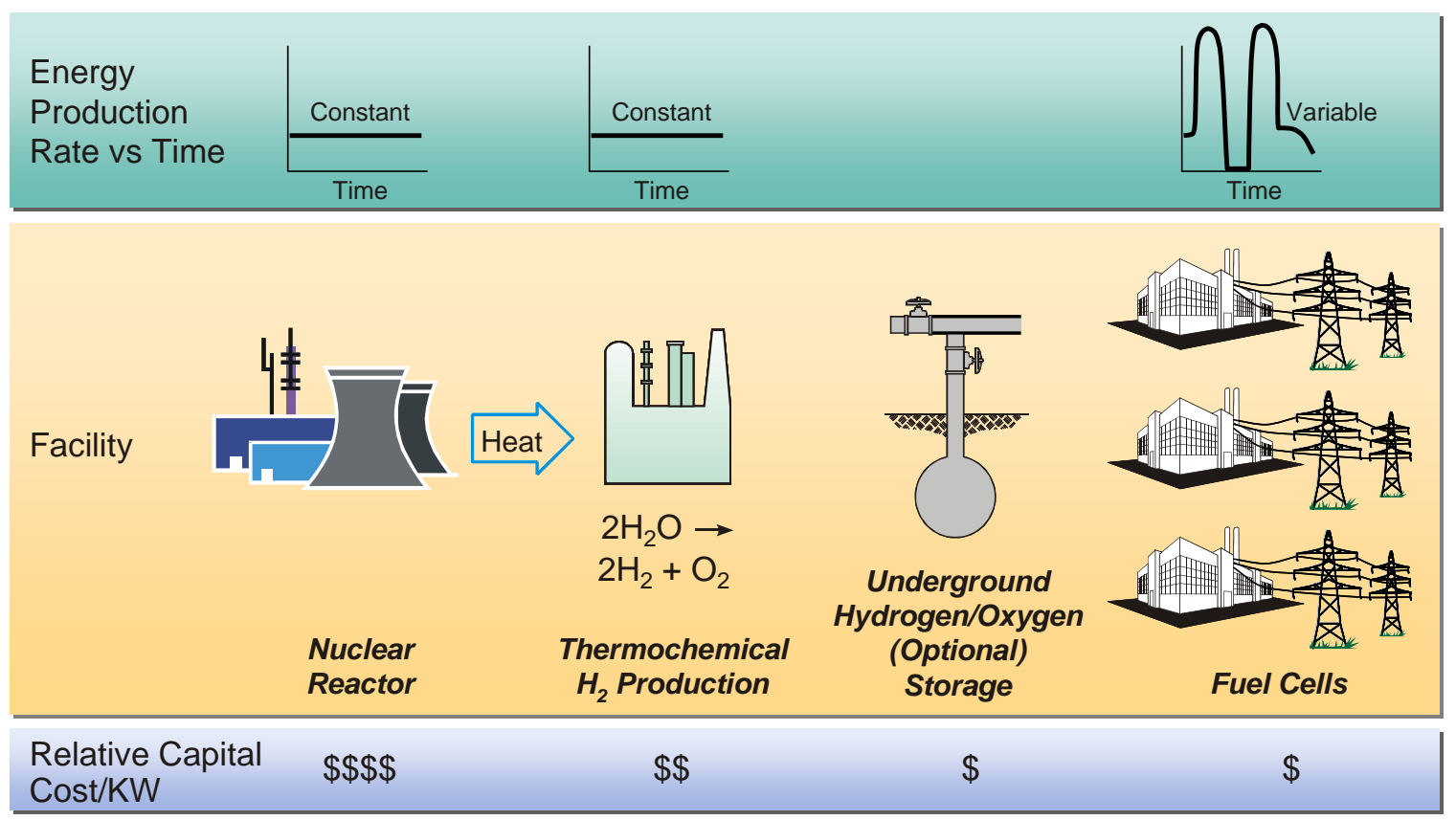

Fig. ES.1. Peak-electricity nuclear system, including relative costs for production.

Today the demand for peak and intermediate electrical load is met primarily by gas turbines burning natural gas. The capital costs of gas turbines are about $\$ 500 / \mathrm{kW}(\mathrm{e})$, and efficiencies are near $50 \%$. Hydrogen is a premium fuel relative to natural gas. Thus, if hydrogen is to be used to meet intermediate and peak electrical loads, there must be a benefit in using hydrogen rather than natural gas. The incentive for using PENS is that it produces hydrogen and oxygen under conditions that may make possible very low-cost, high-efficiency fuel cells that have capital costs significantly lower than those for gas turbines.

The economic viability of PENS is dependent upon three conditions: (1) nuclear hydrogen production under steady-state conditions at competitive costs; (2) the existence of low-cost, large-scale hydrogen storage (storage costs similar to that of natural gas); and (3) significantly lower capital costs of hydrogenoxygen fuel cells in large complexes, compared with costs for gas turbines (the competition to meet peak and intermediate electrical loads). The potential low cost for the fuel cells is based on PENS characteristics: (1) economies of scale associated with the large fuel-cell facilities; (2) a feed of pure hydrogen to boost fuel-cell performance; (3) the use of oxygen from the thermochemical hydrogen production system, rather than air, to reduce fuel-cell capital costs per kilowatt (electrical) and increase efficiency; and (4) the availability of low-cost heat to ensure safe oxygen storage. The goal of the federal government is to develop fuel cells that have costs of $\sim \$ 50 / \mathrm{kW}(\mathrm{e})$ when fed hydrogen and air for automotive applications. While it is unknown whether these goals can be met, the capital costs of fuel cells for PENS will be substantially less than those for vehicle applications because the scale of operations is about 10,000 times larger, an industrial facility does not have the weight and size constraints associated with vehicles, and the use of oxygen boosts fuel-cell power output by several times while increasing efficiency. The projected fuel-cell efficiency is about $70 \%$ with pure oxygen. 
In this context, it is noted that gas turbines are heat engines. Converting gas turbines to hydrogen does not significantly improve their performance. Furthermore, the use of oxygen does not significantly improve their efficiency, because gas turbine efficiency depends upon peak operating temperatures. Although the use of oxygen (rather than air) would increase peak operating temperatures, real-world peak turbine temperatures are limited by the availability of high-temperature materials. For example, air-fired combustors are capable of higher temperatures than turbine blades can currently accept. Fuel cells that require hydrogen as fuel (particularly those that also use oxygen) bypass these limitations.

The same system can provide spinning reserve. "Spinning reserve" is the electrical production capacity on the electrical grid to provide power in the event of an unexpected shutdown of a power plant or a grid failure. The August 14, 2003, blackout of much of the East Coast would probably not have occurred had there been sufficient spinning reserve that was properly distributed.

The major technical and economic challenge in providing spinning reserve is that the additional electrical production must come on-line very rapidly upon the failure of another electrical generating plant or upon the failure of part of the electrical grid. This is accomplished by having power plants at part load with their turbines spinning. This allows the rapid increase in power generation when required. However, this approach has associated high costs. Fuel cells have a unique capability; they can, in a fraction of a second, go from no power output to high power output. Because of this characteristic, one of the major existing markets for fuel cells is for computer data centers, where there is a very high cost associated with temporary power outages - even those that last a fraction of a second. The development of PENS creates a new set of options with new and unique capabilities to provide spinning reserve, improve grid reliability, and improve electric power quality. Significant work will be required to understand the technical and economic implications of this technology for this application. 


\section{INTRODUCTION}

Production of hydrogen using nuclear energy has several technical and economic characteristics. Economics require large expensive plants with large energy outputs. The capital costs are high, but the operating costs are very low. Consequently, nuclear energy can be a low-cost energy source if the plants are operated at full capacity. On the other hand, nuclear energy is expensive if the plants are operated at only a fraction of their capacity. As a consequence, for economic viability, the first-generation nuclear hydrogen plants need large hydrogen markets that can fully utilize their output. If the output is not fully utilized, the hydrogen will be very expensive and uneconomical.

These characteristics of nuclear energy create a classical "chicken-and-egg" type of problem. A large hydrogen market is needed to justify building a nuclear hydrogen plant. However, the development of a large-scale market depends upon the existence of low-cost, large-scale hydrogen production units. There are two solutions to this problem. The first is to delay the deployment of nuclear hydrogen systems until a large market for hydrogen is developed, with the initial hydrogen being provided by other technologies. In such a scenario, nuclear hydrogen production follows the development of the hydrogen economy. The second alternative is to find "early" markets in which all the hydrogen produced by a large nuclear hydrogen plant can be economically used. One potential market has already been identified: hydrogen production for the upgrade of heavy oils in refineries to liquid fuels. A second set of tightly coupled potential markets is proposed herein: nuclear hydrogen for production of peak electricity and spinning reserve to stabilize the electrical grid.

If these tightly coupled markets are economically viable for nuclear hydrogen, an early market exists for nuclear hydrogen that has several unique characteristics:

- Size. The market is approximately equivalent in size to the existing nuclear electric enterprise in the United States.

- Geographical location. The market exists throughout the continental United States, and thus the development of the technology would benefit the entire country.

- Domestic market. This market cannot be exported to foreign countries, which is not the case for markets such as oil refineries. For example, there has been a large growth in the number of refineries in the Caribbean because of the availability of lower-cost natural gas.

- Hydrogen infrastructure requirements. The entire market is within the utility industry and does not require development of an external market for hydrogen or a significant hydrogen infrastructure beyond the utility site.

- Utility market. The entire market is within the electrical utility industry, which operates all of the existing nuclear power plants. This avoids many of the institutional issues associated with another industry having to learn to operate nuclear power plants.

- Industrial scale. The technology and scale match those of nuclear hydrogen production.

- Market availability. The market exists today.

- Research \& development $(R \& D)$ expenditures. If nuclear hydrogen is economical for this application, the market will be sufficient in size to justify development of nuclear hydrogen production techniques independent of the development of any other market for hydrogen. 
For the technical and commercial development of nuclear hydrogen, understanding early markets is absolutely critical for several reasons.

- Timing. If the market already exists, there are strong incentives to develop the technology today. If the market is 50 years in the future, little incentive exists to initiate an R\&D program at this time.

- Industrial partnerships. Large-scale implementation will require extensive partnerships between government and private organizations. The logical choice of partners depends upon the application. If the application is hydrogen for oil refineries, the logical partners are oil companies. For a utility application using fuel cells, the logical partners are utilities, their traditional suppliers, and fuel-cell companies.

- Technological requirements. The market determines the technical requirements for hydrogen production: steady-state or intermediate production, quality, throughput, purity, etc.

This report is a first description of the system. A general system description is provided in Sect. 2 . Section 3 describes the electrical markets that are the basis for this application of nuclear hydrogen, while Sect. 4 discusses specific technological components. Section 5 discusses economics, while Sect. 6 identifies other implications of the successful development of a peak-electricity nuclear system (PENS). Section 7 defines the systems R\&D required to define the technology and determine if this early market for nuclear hydrogen is realistic. 


\section{THE PEAK-ELECTRICITY NUCLEAR SYSTEM}

The demand for electricity varies daily, weekly, and seasonally. As a result, the market price of electricity varies by an order of magnitude as a function of time. The variability of the price of electricity creates the potential for a large nuclear hydrogen market aimed at producing electricity at those times of day when the price of electricity is at its maximum. A PENS using nuclear hydrogen consists of three major components (Fig. 2.1):

- Hydrogen production. A nuclear power plant with an associated thermochemical or electrolysis plant produces hydrogen and oxygen from water at a constant rate.

- Hydrogen and oxygen storage. Underground facilities are used for the low-cost storage of hydrogen and oxygen (optional). Such facilities (e.g., caverns and depleted natural gas fields) are the traditional approach to the low-cost storage of natural gas to meet variable demand and are the only known low-cost method to store large volumes of gas. In countries such as Great Britain, caverns have been used for many decades for the low-cost storage of hydrogen.

- Hydrogen-to-electricity conversion. Large banks of fuel cells are used to convert hydrogen to electricity during periods of higher-priced electricity. For every megawatt of steady-state hydrogen production from the nuclear reactor, the fuel cells would be capable of producing several megawatts of electricity.

The economic viability of PENS is based on several requirements: (1) nuclear hydrogen production under steady-state conditions can be accomplished at competitive costs and (2) the capital costs of hydrogen-oxygen fuel cells in large complexes will be significantly lower per kilowatt (electrical) than those of gas turbines (the primary existing technology to meet peak and intermediate electrical loads). If these assumptions are correct, hydrogen produced at a constant rate can be used to make electricity at times of peak value. The potential for low-cost fuel cells in this application is based on two considerations. First, although the current capital costs of fuel cells exceed those of gas turbines, the capital-cost goal for automotive fuel cells is a $\$ 50 / \mathrm{kW}(\mathrm{e})$ - significantly below the $\$ 500 / \mathrm{kW}(\mathrm{e})$ cost of gas turbines. The national initiative to use hydrogen in vehicles is partly based on the future projected costs of these fuel cells. Technology suggests that such goals are possible. Second, several technical characteristics of PENS are expected to lower the cost of fuel cells for this application relative to other applications.

- Scale. Economies of scale are associated with the large fuel-cell facilities

- Hydrogen. A feed of relatively pure hydrogen from the nuclear hydrogen production system (not hydrogen from steam reforming of natural gas) maximizes fuel-cell output, efficiency, and reliability.

- Oxygen. The use of pure oxygen, rather than air, reduces fuel-cell costs per kilowatt (electrical) and increases fuel-cell efficiency. In many fuel-cell systems, the use of oxygen rather than air increases cell output by several hundred percent (EG\&G Technical Services 2002). This is in contrast to heat engines, such as gas turbines, where the difference in power output with air versus oxygen is very small.

- Safety. Although oxygen is a component of air, pure oxygen is hazardous and toxic. Ground-level plumes can be extremely dangerous. However, oxygen can potentially be safely stored in large quantities if it is heated to above ambient air temperature before storage. Should a major failure occur, because the warm oxygen is lighter than the ambient air temperature, the oxygen travels upward and safely mixes with the air. Nuclear reactors can provide low-cost, low-temperature heat without major penalties in terms of production of hydrogen or electricity. 


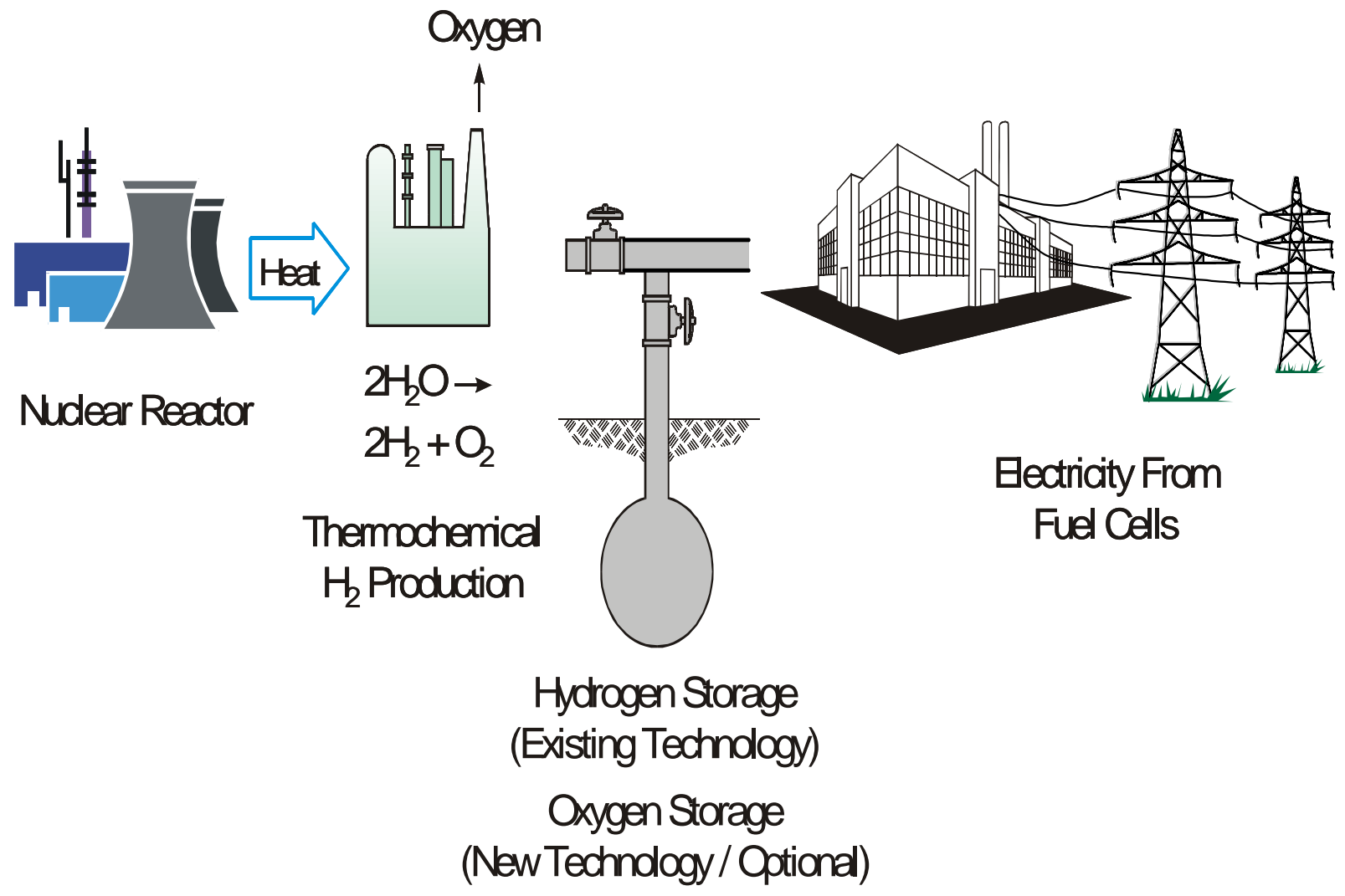

Fig. 2.1. Peak-electricity nuclear system.

The same system can be used to provide spinning reserve. "Spinning reserve" is the electrical production capacity on the electrical grid to provide power in the event of an unexpected shutdown of an electricgenerating plant. Without spinning reserve, any grid or power-plant failure results in the collapse of the electrical grid and blackouts. Significant costs are associated with maintaining spinning reserve.

The initial assessment indicates that the specific characteristics of this market match the specific characteristics of a nuclear hydrogen production system. That is, nuclear hydrogen has potentially unique competitive advantages relative to other hydrogen generation technologies if the competing technologies produce hydrogen at the same costs.

- Scale. The scale of nuclear hydrogen generation matches the required scale for economical storage of hydrogen and oxygen. Small-scale dispersed hydrogen production would require a large expensive pipeline infrastructure to collect the hydrogen for low-cost underground hydrogen storage. (Underground storage is the only available low-cost hydrogen storage technique.) 
- Fuel cells with oxygen. The use of oxygen, rather than air, in fuel cells (EG\&G Technical Services 2002) substantially increases their efficiency and reduces the capital costs per kilowatt (electrical). Thermochemical nuclear hydrogen production results in oxygen as well-as an unavoidable by-product.

- Oxygen storage. The nuclear reactor can provide at low cost the large quantities of low-quality heat required to ensure safe oxygen storage. 


\section{ELECTRICAL MARKETS}

\subsection{TIME-OF-DAY VARIATIONS IN ELECTRICITY COSTS}

\subsubsection{Time-of-Day Pricing and Costs}

The demand for electricity varies with time of day-being high in the daytime and low at night. In unregulated electrical markets, this fluctuation results in high costs for electricity during peak periods of electricity demand. An example of such variations is the price of electricity [\$/MW(e)-h] in Alberta, Canada, during 2002 (Fig. 3.1). In regulated markets, the price of power may be constant. However, the utility must build facilities to meet peak electrical demand. The cost to produce that electricity is significantly higher than the cost of electricity during periods of low demand. The plants producing peak electricity produce power for only a limited number of hours per year and do not operate continuously.

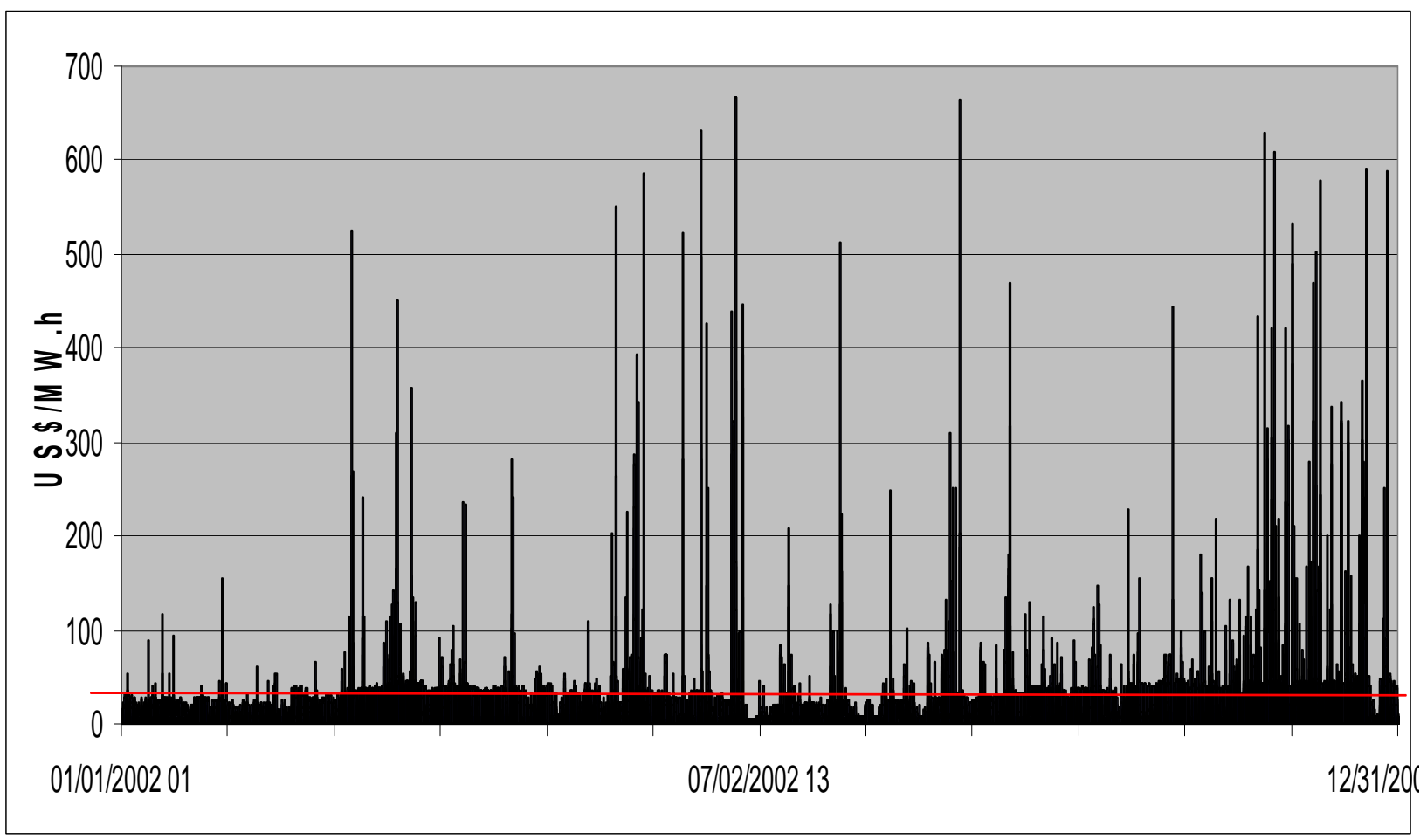

Fig. 3.1. Price of electricity [\$/MW(e)-h] as a function of time in Alberta, Canada. 


\subsubsection{Existing Methods to Meet Peak and Intermediate Power Demands}

Several methods exist to meet peak and intermediate power demands. These processes are the competition to PENS and provide the basis to define the requirements for an economic system.

Many hydroelectric facilities operate primarily when the demand for electricity is high, with water being stored above the dam until needed. However, in most of the United States, the demands far exceed the capabilities of hydro power plants to produce electricity during periods of peak power demand. This situation exists because (1) the total hydroelectricity production capacity of the United States is only a small fraction of the required electrical capacity; (2) hydroelectric capacity exists only in some parts of the country; and (3) the operation of hydroelectric dams is constrained by other requirements such as preventing floods, ensuring navigable waterways, preserving recreational resources, and preserving fishery resources.

When and where insufficient hydroelectricity exists, gas turbines are used to meet peak and intermediate electric demands. Gas turbines have relatively low capital costs [\$500 to 600/kW(e)] and high operating (fuel) costs and can be operated part-time. In the last several years, the price of natural gas has increased dramatically; consequently, the cost of electricity from these units has also increased dramatically.

Electricity can also be produced at night, stored, and then distributed in the daytime to meet peak demands. Special facilities are built that buy inexpensive electricity at night and sell it at a higher price during times of peak demand. While batteries can accomplish this task, such an approach has generally not been economic. The preferred method has been hydro-pumped storage. In a pumped storage facility, water is pumped uphill at night when the cost of electricity is low. The water then flows downhill through hydroelectric turbines to produce electricity at times of high power demand. Figures 3.2 and 3.3 show the pumped storage facility operated by the Tennessee Valley Authority (TVA). This facility (Raccoon Mountain) has a capability to produce $1530 \mathrm{MW}(\mathrm{e})$ at times of peak demand. Figure 3.2 shows the upper storage lake, while Fig. 3.3 shows the underground powerhouse.

Last, several compressed air energy storage (CAES) systems have been built to meet peak electrical demand. In these systems, off-peak power from the grid is used to pump air into underground storage caverns at high pressure. At times of peak demands, the compressed air is fed to gas turbines to produce electricity. Normally, about two-thirds of the energy from a gas turbine is used to compress incoming air into the turbine while one-third of the energy is used to make electricity. With CAES, the energy required for air compression is obtained from off-peak electrical power. Because no energy of air compression is then needed to operate the turbine during times of peak power demand, the output of the turbine is effectively tripled for peak power production. Typical capacities for CAES systems are between 50 and $300 \mathrm{MW}(\mathrm{e})$.

\subsection{SPINNING RESERVE}

Electrical grids require spinning reserve. PENS can reduce or eliminate other forms of spinning reserve on the utility grid, producing large cost savings. If a utility requires nine power plants to meet the demand for electricity at any point in time, it will have a minimum of ten power plants on-line, each operating at somewhat less than full capacity. If one of the plants fails for any reason, the other plants take up the load. If no excess production capability exists and electricity demand exceeds supply, the grid will collapse, causing a power blackout. If other electrical-generating plants are to quickly pick up the load from a failed generator before the collapse of the electrical grid, they must be up to speed. In other words, their generators must be spinning, thus the term "spinning reserve." Operating power plants on partial load with the generators spinning is a necessary but expensive requirement for a reliable electrical power system. The August 14, 2003, blackout of much of the East Coast might not have occurred had there been sufficient spinning reserve in the appropriate locations. 


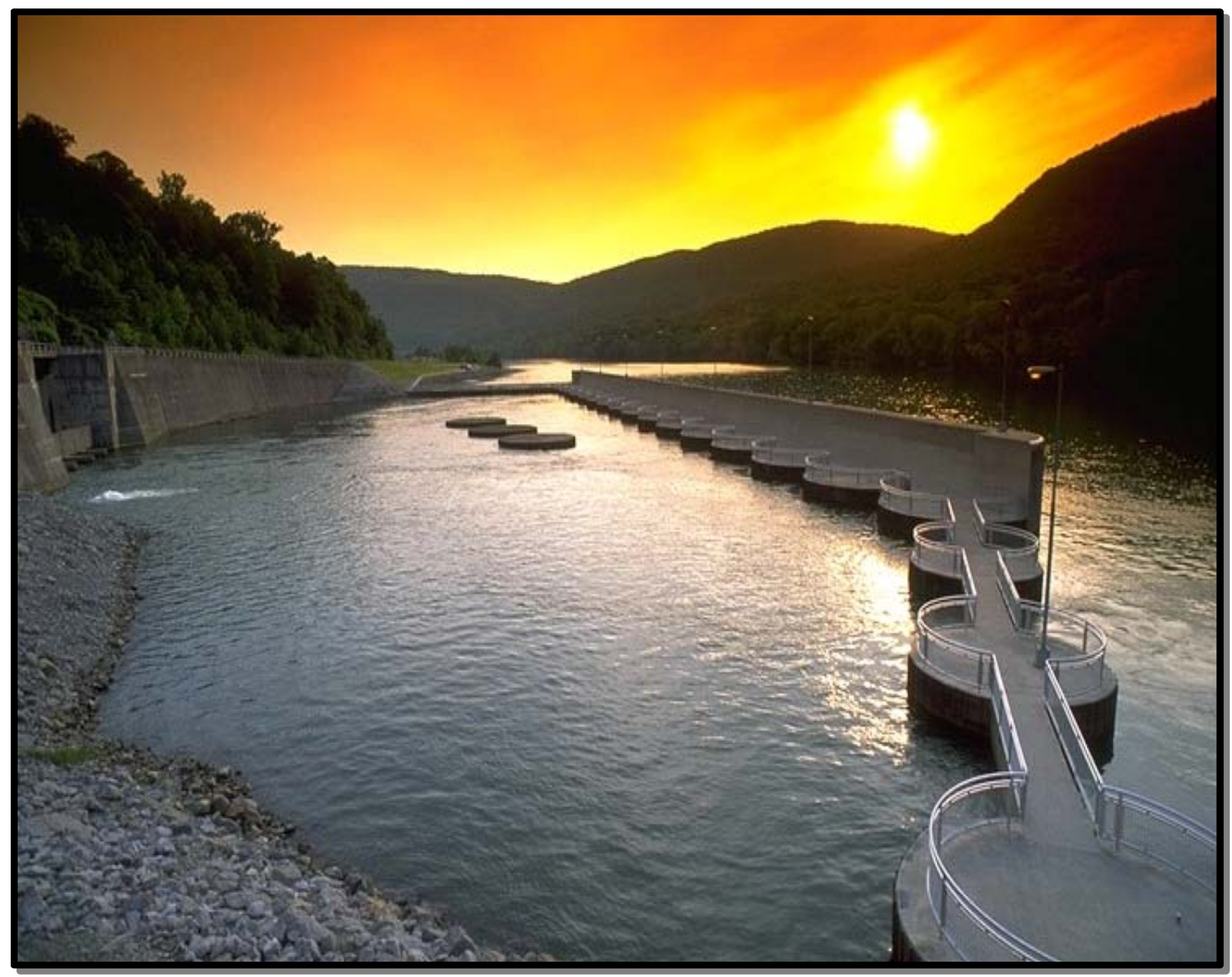

Fig. 3.2. Upper water storage and intake structures of the Tennessee Valley Authority Raccoon Mountain Pumped Storage Plant. (Photograph courtesy of the Tennessee Valley Authority) 


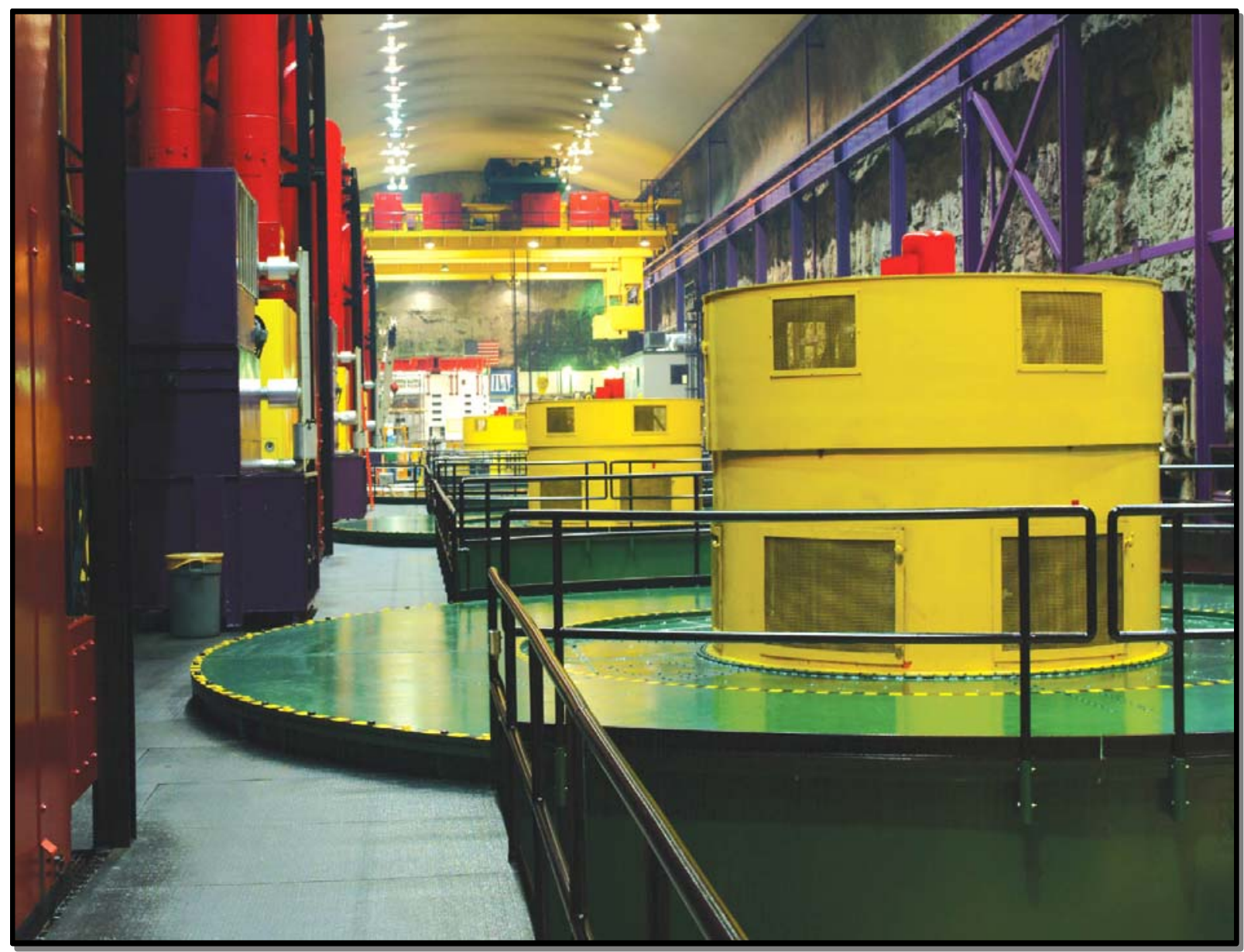

Fig. 3.3. Underground powerhouse of the Tennessee Valley Authority Raccoon Mountain Pumped Storage Plant. (Photograph courtesy of the Tennessee Valley Authority) 
Fuel cells are batteries in which the chemical reagents are gases or liquids that flow into the battery. Like a battery, a fuel cell can start instantaneously and thus operate as a spinning reserve. Fuel cells can replace other forms of spinning reserve and can offer the potential for major cost savings. From a technical perspective, fuel cells are ideal for this application. Today, one of the primary commercial applications for large industrial fuel cells is to serve as backup power for bank credit-card centers. Such centers electronically confirm to the merchant at the point of sale that the credit card is not stolen and that that the charges do not exceed the credit limit. Power failures, including blips in power that cause computers to restart, are extremely expensive because they shut down the national credit-card system. Fuel cells can respond much more rapidly than other methods of spinning reserve and thus ensure constant power.

While the concept of spinning reserve is simple, the process of determining what is sufficient spinning reserve and calculating the economic benefits is extremely complex. This is particularly true with fuel cells, which have a capability not seen in other methods of providing spinning reserve - an instant-start capability. What is evident is that deployment of PENS would greatly enhance grid stability and have clear economic benefits. 


\section{PENS DESCRIPTION}

The major components of PENS are described in further detail in the following sections.

\subsection{HYDROGEN PRODUCTION}

The leading candidates (U.S. Department of Energy 2003) for low-cost, large-scale hydrogen production are thermochemical processes using nuclear heat. These processes involve a series of chemical reactions in which the net result is that high-temperature heat and water produce hydrogen and oxygen. Various studies (Shiozawa et al. 2000; Farbman 1976) project hydrogen thermochemical production costs as low as $60 \%$ of those for electrolysis, with long-term potential heat-to-hydrogen efficiencies in excess of $60 \%$ (i.e., the potential for major improvements over time). Heat-to-hydrogen efficiency is the percentage of heat energy that is converted to energy in the form of hydrogen. It is strongly dependent upon the temperature of the heat, with higher efficiencies occurring as the temperature increases. Unfortunately, the experience of the chemical industry is that the failure rate of high-temperature equipment is extremely

high if the plant cycles up and down in temperature. As a consequence, it is likely that the hydrogen must be produced at a constant rate.

Chemical plants have large economics of scale. Plant size is generally limited only by market demand or technological limits. In North America, most hydrogen is produced by steam reforming of natural gas. New world-class single-train hydrogen plants are typically designed to produce $5.7 \mathrm{H}^{6} 0^{6} \mathrm{~m}^{3} / \mathrm{d}$ $\left(200 \mathrm{H}_{10} 0^{6} \mathrm{ft}^{3} / \mathrm{d}\right)$ of hydrogen, with a recent announcement to build an $8.5 \mathrm{H} 10^{6} \mathrm{~m}^{3} / \mathrm{d}\left(300 \mathrm{H} 10^{6} \mathrm{ft}^{3} / \mathrm{d}\right)$ facility. If we assume that a nuclear thermochemical process (when commercially deployed in 15 to

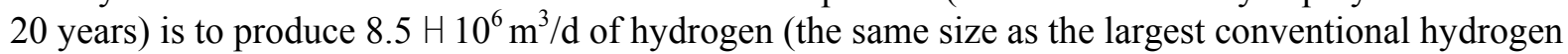
plant currently being planned), the nuclear reactor or reactors must deliver $\sim 2400 \mathrm{MW}(\mathrm{t})$ of hightemperature heat to the process. This assumes the thermochemical process is $50 \%$ efficient in converting heat and water to hydrogen.

The scaling factor (Miller and Duffy 2003) for existing natural-gas-fueled thermochemical hydrogen plants is estimated to be 0.66 . This implies that if the plant size is increased by 4 , the capital cost increases by only a factor of 2.5 ; that is, the capital cost of the larger facility is only $62 \%$ of that for the smaller facility per unit of capacity. The scaling factor (Goosseng et al. 2003) for the nuclear hybrid thermochemical process was estimated at 0.54 ; that is, the capital cost of the larger facility (4 times the size of the smaller facility) is only $53 \%$ that of the smaller facility per unit of capacity. The economics of chemical plants indicate that thermochemical nuclear hydrogen facilities must be large to achieve good economics.

The alternative to thermochemical process plants is the large-scale electrolysis of water to produce oxygen and hydrogen. This was the first industrial method for producing hydrogen to make fertilizer and was the primary method for fertilizer production for several decades in the twentieth century. Electrolysis was ultimately replaced by steam reforming of natural gas. In its 2004 report, the National Research Council recommended a significant effort to increase electricity-to-hydrogen efficiency to $70 \%$ of the lower heating value of hydrogen, with a target capital cost of $\$ 125 / \mathrm{kW}(\mathrm{e})$ (U.S. National Research Council 2004). With a high-temperature reactor, the efficiency of converting heat to electricity is estimated at 50\%; thus, the overall efficiency of heat to hydrogen by electrolysis (if goals are met) would be $35 \%$. Because this latter figure is significantly less than is potentially possible for thermochemical cycles, the incentive exists to develop thermochemical cycles. However, electrolysis is an existing available technology. 


\subsection{HYDROGEN AND OXYGEN STORAGE}

Only one method presently exists for the low-cost storage of hydrogen and oxygen - storage as compressed gases in large underground facilities. This is the primary technology used to store natural gas (U.S. Energy Information Agency 1995). In the natural gas industry, the most rapid consumption of natural gas occurs in winter. However, it is uneconomical to design transcontinental pipelines and natural gas treatment plants to meet peak natural gas demands. Instead, the natural gas is produced and transported at a relatively constant rate throughout the year. A variety of different types of large underground storage systems in different geologies at locations near the customer are used to store the excess natural gas produced during the summer. This minimizes the cost of the long-distance natural-gas pipeline system and improves reliability by locating storage facilities near the customer. In the winter, these underground storage facilities provide the natural gas to meet customer demands.

There are three types of underground gas storage facilities (Fig. 4.1).

- Manmade caverns. Underground caverns are mined with access to the surface with wells. The most common type of cavern is in salt domes, where the cavern is made by pumping down fresh water and dissolving out the salt. Salt dome caverns are used to store oil, natural gas, hydrogen, and a wide variety of chemical products. When compressed gases are stored, the gas pressure depends upon the inventory of compressed gases in the cavern. As the compressed gas is removed, the pressure drops.

- Pressure-compensated manmade caverns. Underground caverns are mined with access to the surface with wells. In addition, a surface lake connected to the bottom of the manmade cavern is created. The water pressure from the surface lake results in a constant pressure in the cavern that is equal to the hydraulic head of the water. The compressed gas is stored and delivered at a constant pressure. This option requires (1) a rock that does not dissolve in water and (2) a compressed gas that does not have a high solubility in water.

- Porous rock with cap rock. In many parts of the United States, porous rock exists with an impermeable cap rock above it that forms a natural trap for gases (inverted "U" shape). Wells are drilled into the porous rock, and injected gas pushes out whatever other fluids exist in the porous rock. Much of the world's natural gas is found in this type of geological trap. Because the natural gas has been trapped for tens of millions of years, nature has demonstrated that the cap rock is extremely impermeable to fluids. Old natural gas fields near major cities are often converted into natural gas storage facilities. Other geological traps have saltwater. In these types of structures, the compressed gas creates a gas bubble and pushes the saltwater aside.

The total existing natural gas storage capacity in the United States is $8.4 \times 10^{12} \mathrm{ft}^{3}$, which is equivalent to about one-third of the natural gas consumed in the United States in 1 year. Table 4.1 identifies the existing underground natural gas storage facilities by type and capacity. Three types of storage systems are used: (1) mined salt caverns, (2) aquifers with cap rocks, and (3) depleted oil and gas fields. These facilities are large, even relative to a large nuclear hydrogen production facility, with average storage capacities between 10 and 20 billion cubic feet. The usable capacity depends upon the required pressure at which the natural gas must be delivered to the pipeline and the rate of delivery. For high-pressure gas delivery, the capacity is about one-half, with one-half of the gas used as buffer gas to maintain storage facility pressure. Were such storage facilities used for hydrogen, the existing system would be significantly larger than required for PENS deployment across the entire United States. For PENS, the effective storage capacity of an underground storage facility would be closer to its ultimate capacity because the hydrogen would be delivered at lower pressures than required for long-distance pipeline transport. 


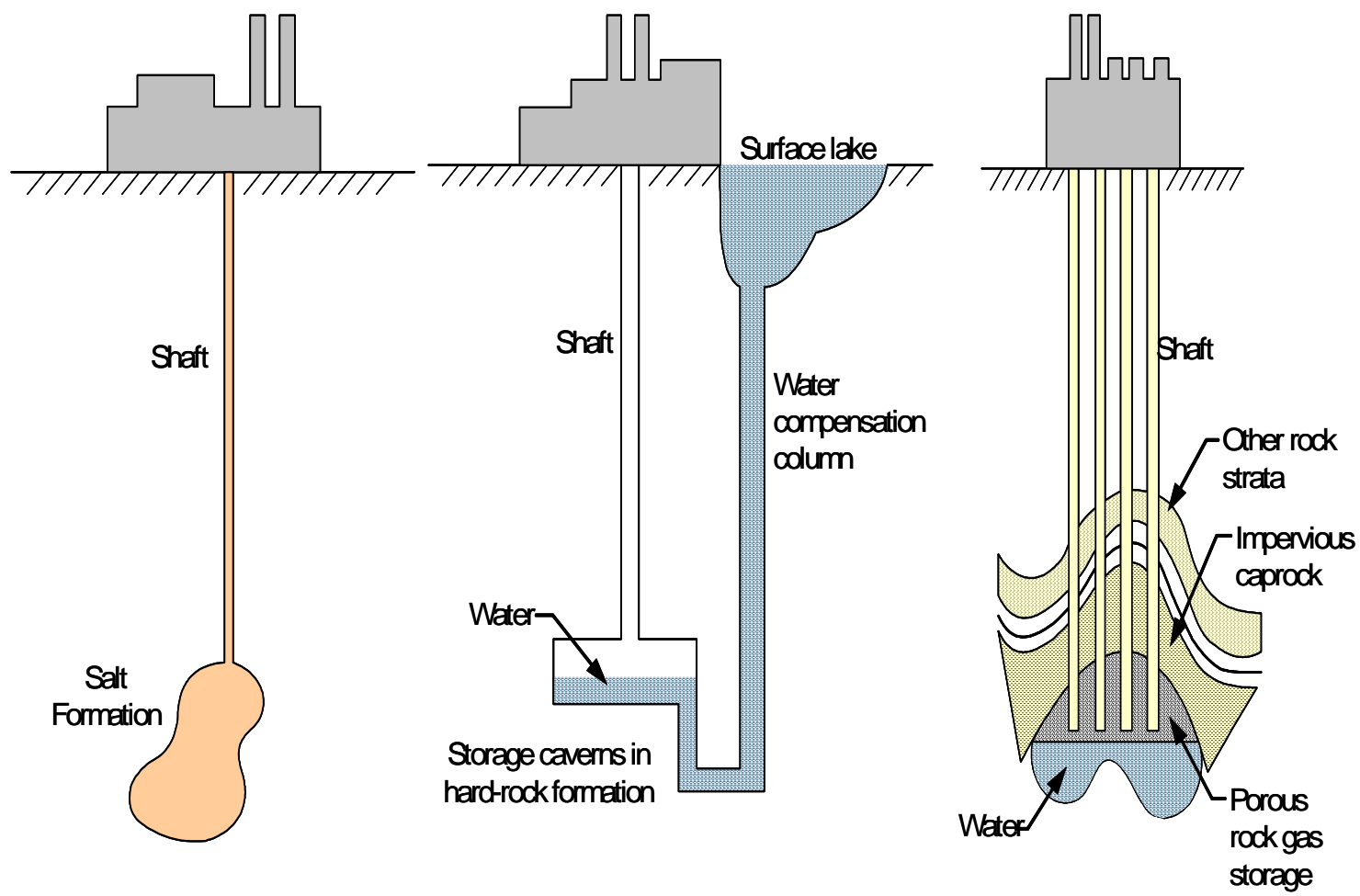

Fig. 4.1. Technologies for underground storage of compressed gases.

Table 4.1. U.S. underground natural gas storage capacity in 2001

\begin{tabular}{|c|c|c|}
\hline Type of storage capacity & Number of facilities & $\begin{array}{c}\text { Capacity } \\
\left(\mathbf{1 0}^{\mathbf{9}} \mathbf{f t}^{\mathbf{3}} \mathbf{)}\right.\end{array}$ \\
\hline Salt caverns & 28 & 218 \\
\hline Aquifers & 39 & 1195 \\
\hline Depleted fields & 351 & 7002 \\
\hline Total & 418 & 8357 \\
\hline
\end{tabular}


The capital cost of an underground facility to store one GW-year of hydrogen (lower heating value) is estimated to be about $\$ 200-400$ million $(\$ 0.80-1.60 / \mathrm{kg})$. The value of the hydrogen stored in such a facility will exceed the capital cost of the facility. This capital cost is sufficiently low that serious consideration can be given to seasonal storage of hydrogen. The capital cost estimate (1) assumes the cost per unit volume stored is the same of hydrogen and natural gas and (2) is based in reported capital costs for planned natural gas storage facilities (Thompson 1997).

In addition to natural gas storage, underground caverns are used for CAES systems with gas turbines that are designed for peak electrical production (Sect. 3.1.2). Currently, two such facilities exist in the world: the 300-MW(e) E. N. Kraftwerk plant in Huntorf, Germany, with $300,000 \mathrm{~m}^{3}$ of gas storage at depths $>600 \mathrm{~m}$, and the 110-MW(e) Alabama Electric Corporation plant in McIntosh, Alabama, with 5.32 million cubic meters of gas storage. Another plant is under development by Norton Energy Storage LLC in the United States. It is a multiphase project that will use an existing limestone mine $700 \mathrm{~m}$ underground with a capacity of 10 million cubic meters. The ultimate site capability is for a peak power production rate of $2500 \mathrm{MW}(\mathrm{e})$. The power output rating is dependent upon the depth of cavern (allowable peak gas pressure), the cavern volume, and the time period over which it is desired to deliver peak power. These facilities provide a second source of information on the economics of large-scale storage of gases.

For the same reasons indicated above (economics and matching demand), several countries store hydrogen in underground caverns. Hydrogen is produced in expensive plants that operate at a constant rate. The demand for hydrogen, however, varies. Thus, the underground caverns are used to store hydrogen until needed. The historical experience base is that hydrogen storage is very safe-particularly in terms of risks to people located off-site. Because hydrogen is lighter than air, should a leak occur, the hydrogen rapidly rises and is diluted with air.

While PENS does not require oxygen storage, the preliminary assessment indicates strong economic incentives to store oxygen as well as hydrogen for the fuel cells. Underground storage would also be used for the oxygen. Storage in geologies where there are no burnable materials (salt, granite, etc.) is a near-term option, while storage with materials that can react with oxygen is a longer-term option. Experience in the underground behavior of oxygen in geologies with burnable materials already exists, and experiments are being conducted using "oxygen fire flood" for the recovery of oil from depleted oil fields. In these experiments, oxygen is injected down a series of wells and the residual oil is ignited. The burning of the residual oil in the rock creates heat, pressure, and carbon dioxide. This combination is used to push the remaining oil from the porous rock to other wells some distance away to increase the ultimate recovery of oil. The approach would be expected to open up the reservoir for possible future use for storage of oxygen and hydrogen. This is an area of current research and clearly a longer-term underground storage option.

About $20 \%$ of air is oxygen; however, pure oxygen is hazardous and dangerous. Pure oxygen can cause spontaneous combustion of clothing and many other objects. If high-pressure oxygen is stored and released, it cools as it is depressurized. Consequently, if a large-scale accidental release of oxygen occurs, the oxygen can form a cold high-density ground-level plume that floats off-site (Fig. 4.2), in contrast to the behavior of hydrogen, which becomes warmer and lighter when depressurized.

Consequently, if oxygen is to be stored in large quantities, safety is a major design requirement.

A method to avoid this safety hazard has been identified. If the oxygen is heated 20 to $40^{\circ} \mathrm{C}$ before storage, should a release occur, the oxygen will have a lower density than that of air. This allows any oxygen plume to rise and be diluted by air. Nuclear reactors produce large quantities of low-cost heat, which would be suitable for heating the oxygen for safe storage. Other methods to ensure safety may exist as well, and significant work will be required in this area. 


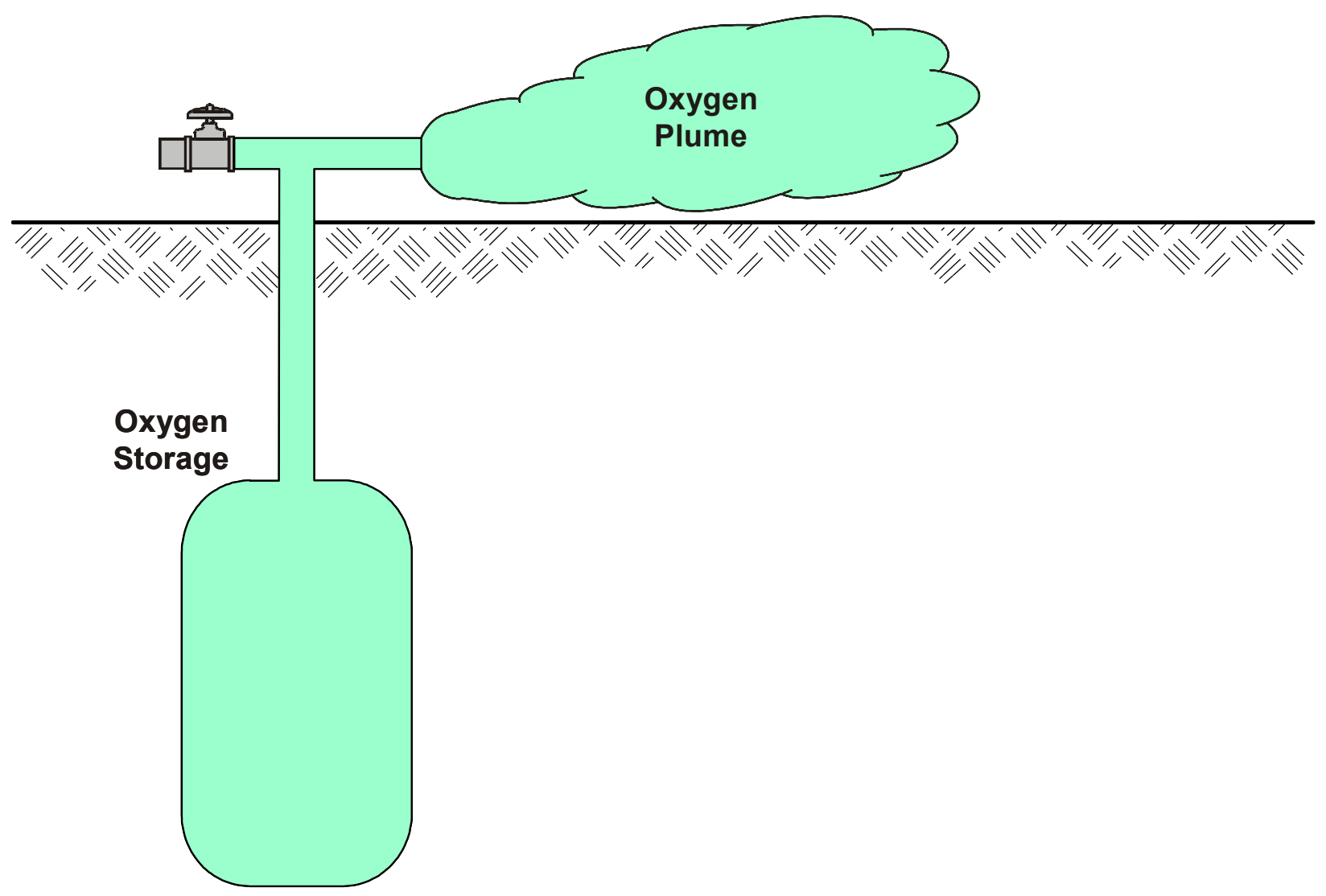

Fig. 4.2. Ground-level plume resulting from large-scale oxygen release.

Underground storage is the only low-cost method to store gases. The economics of underground storage require large facilities with storage volumes measured in millions of cubic meters of hydrogen or oxygen.

\subsection{FUEL CELLS AND OTHER METHODS FOR INTERMEDIATE AND PEAK ELECTRICITY PRODUCTION}

\subsubsection{Fuel Cells vs Gas Turbines}

PENS depends upon efficient, inexpensive methods to convert hydrogen to electricity. Fuel cells potentially have these characteristics, especially when compared with gas turbines, the traditional method to meet peak and intermediate electric demand. While gas turbines have peak efficiencies near $50 \%$, fuel cells are expected to ultimately have efficiencies between 70 and $80 \%$. The long-term cost trends indicate that fuel cells will be less expensive than gas turbines. 
The use of pure oxygen can substantially increase efficiency and reduce the costs of fuel cells. In contrast, pure oxygen is not a significant benefit to a gas turbine. The efficiency of gas turbines is controlled by the peak temperature of the gas reaching the first set of turbine blades, a temperature that is limited by the available materials of construction. This peak temperature is easily reached by burning natural gas in air. Oxygen cannot be used because it would further raise combustion temperatures and destroy the high-temperature turbine blades.

\subsubsection{Fuel-Cell Types}

Five classes of fuel cells, each with particular characteristics, presently exist (EG\&G Technical Services 2002). A detailed assessment with evaluation of information from the literature will be required to determine which type or types are best suited for PENS under various scenarios (with and without pure oxygen). The preferred option will depend upon (1) future progress on each type of fuel cell and (2) the specific requirements and characteristics of PENS. Based on the requirements for PENS, an initial assessment indicates that the leading candidates are alkaline and polymer fuel cells. These two types of fuel cells have the best capabilities for rapid transient power operations, operate below $100^{\circ} \mathrm{C}$ (avoid potential thermal fatigue of materials in high-temperature fuel cells), have potentially low costs, and have good performance with pure oxygen. Based on the existing knowledge, alkaline fuel cells are superior for this application. However, polymer fuel cells are being developed for transport applications because of their small volume - an important characteristic for vehicles but not for PENS. The very large research programs for vehicle fuel cells may lower the costs of polymer fuel cells to make them the preferred option.

\subsubsection{Alkaline fuel cells}

Alkaline fuel cells (Fig. 4.3) are one of the oldest fuel-cell technologies and offer a large experience base. These are the fuel cells used in space operations, including the space shuttle. In this application with pure oxygen, in which weight is a major constraint, the efficiency of alkaline fuel cells is $\sim 60 \%$. For largescale systems, efficiencies may approach $70 \%$. Recent reviews have summarized the status of this technology (McLean et al. 2002; EG\&G Technical Services 2002).

Alkaline fuel cells have a five-layer structure: a gas chamber for hydrogen feed, an anode membrane, a liquid potassium hydroxide electrolyte, a cathode membrane, and a gas chamber for the oxygen feed. The overall chemical reactions are as follows:

$$
\begin{array}{ll}
\text { Anode reaction } & 2 \mathrm{H}_{2}+4 \mathrm{OH}^{-} \rightarrow 4 \mathrm{H}_{2} \mathrm{O}+4 \mathrm{e}^{-} \\
\text {Cathode reaction } & \mathrm{O}_{2}+2 \mathrm{H}_{2} \mathrm{O}+4 \mathrm{e}^{-} \rightarrow 4 \mathrm{OH}^{-} \\
\text {Overall cell reaction } & 2 \mathrm{H}_{2}+\mathrm{O}_{2} \rightarrow 2 \mathrm{H}_{2} \mathrm{O}+\text { electricity + heat }
\end{array}
$$

The water is formed in the potassium hydroxide solution between the membranes. The potassium hydroxide solution is circulated to (1) improve transfer of hydroxide ions within the fuel cell and (2) remove any heat and excess water. 


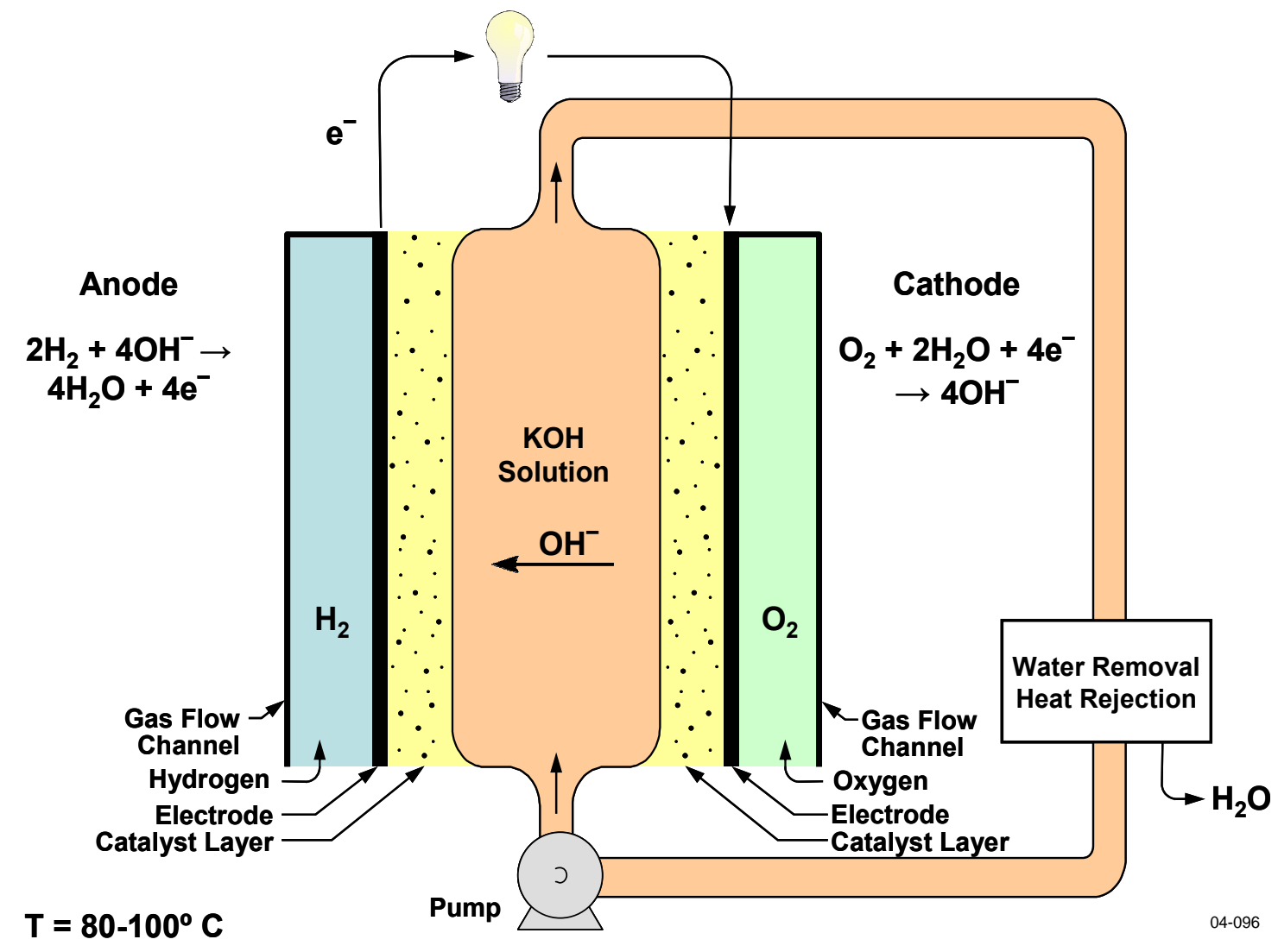

Fig. 4.3. Alkaline fuel cell.

These fuel cells have several major advantages: excellent performance using pure oxygen and hydrogen relative to that of other fuel-cell types; no expensive materials such as platinum catalysts; scalability to large size; low-pressure, low-temperature operation; potentially low cost; and excellent capabilities for transient power operations (Ernst and Nerschook 2004). However, alkaline fuel cells are not receiving major attention for use in cars because of several limitations: (1) low power density, (2) the need for cleanup of the potassium hydroxide solution, and (3) electrolytic poisoning of the fuel cell from carbon dioxide in air. The poisoning occurs because the carbon dioxide reacts with the solution to produce insoluble potassium carbonate, which then plugs up the system. These limitations do not apply to alkaline fuel cells that are fed pure hydrogen and oxygen, such as those used in space vehicles. The limitations identified for alkaline fuel cells are not constraints for PENS. For stationary applications, minimum cost per kilowatt, not size, is the primary requirement. The processing of the hydroxide solution is an intrinsically low-cost operation on a large scale. If PENS uses pure oxygen, no carbon dioxide is present in the feed. Last, the space program provides a large base of experience in the use of these cells with hydrogen and oxygen. 
From an industrial perspective, a large-scale alkaline fuel-cell facility has striking similarities to chlorine production facilities. Chlorine is used for water treatment, is produced on a massive scale, and is one of the largest sectors of the chemical industry. In a chlorine production facility, electricity is used in electrolytic cells to convert a sodium chloride brine solution to chlorine and sodium hydroxide. The facility includes large electrolytic cells, gas-handling systems for toxic gases, alkaline solution (sodium hydroxide) processing systems with heat removal, and electrical power conversion systems. A large alkaline fuel-cell facility has many similarities [electrolytic cells; hazardous gas (oxygen rather than chlorine); alkaline solution processing systems with heat removal; etc.]. These similarities and the extensive knowledge concerning performance with oxygen may enable early development of conceptual designs and relatively reliable cost estimates for a PENS facility based on alkaline fuel cells.

\subsubsection{Polymer electrolyte fuel cells}

Polymer electrolyte fuel cells (Fig. 4.4) are the leading candidates for automotive use because of their potential weight, size, and cost advantages. A distinguishing feature of these fuel cells is that a solidphase polymer membrane is used as the cell separator and electrolyte, thus avoiding the use of liquids such as acids and bases. At present, the cells operate at slightly above room temperature $\left(60-80^{\circ} \mathrm{C}\right)$. However, new ion-exchange membranes are being investigated that may increase this temperature to $160^{\circ} \mathrm{C}$. Recent reviews have summarized the status of this technology (EG\&G Technical Services 2002).

The fuel cells have a multilayer structure: gas-flow channels for the hydrogen feed, an anode with catalyst layer, an ion-exchange membrane, a cathode layer, and flow channels for the air. The overall chemical reactions are as follows:

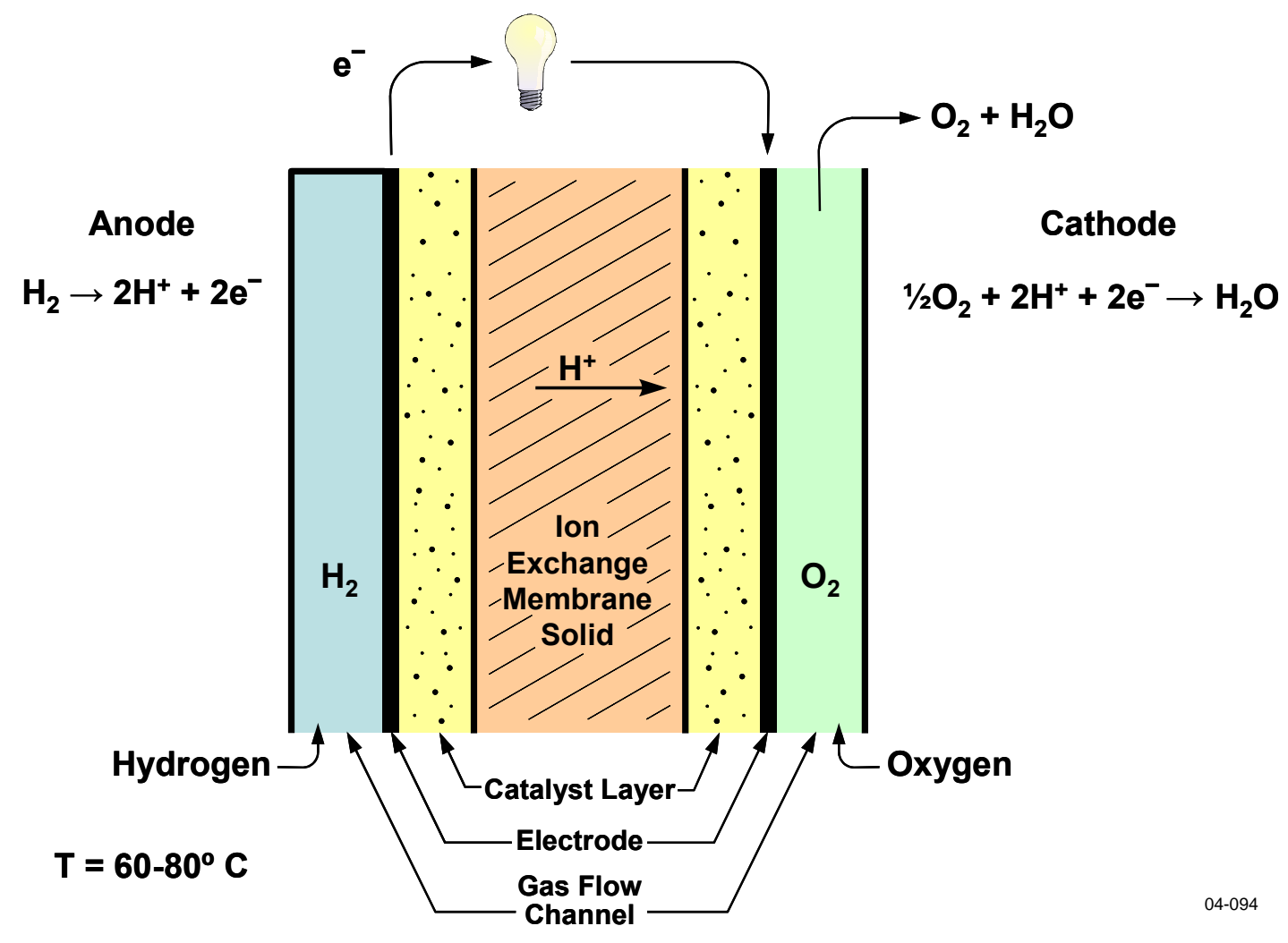

Fig. 4.4. Polymer electrolyte fuel cell. 


$$
\begin{array}{ll}
\text { Anode reaction } & \mathrm{H}_{2} \rightarrow 2 \mathrm{H}^{+}+2 \mathrm{e}^{-} \\
\text {Cathode reaction } & 1 / 2 \mathrm{O}_{2}+2 \mathrm{H}^{+}+2 \mathrm{e}^{-} \rightarrow \mathrm{H}_{2} \mathrm{O} \\
\text { Overall cell reaction } & \mathrm{H}_{2}+1 / 2 \mathrm{O}_{2} \rightarrow \mathrm{H}_{2} \mathrm{O}+\text { electricity + heat }
\end{array}
$$

Because of the massive level of R\&D being expended to reduce costs, the major advantage of these fuel cells is the potential for low capital costs. The goal is to reduce costs to $<\$ 50 / \mathrm{kW}(\mathrm{e})$. Although the cells do require expensive catalysts such as platinum, tests show that replacement of air with oxygen will significantly increase single-cell output and increase efficiency. However, there are two potential limitations when cells are operated on pure oxygen rather than air.

- Heat removal. It is unclear how much the power output can be increased because of heat-load limitations. The greater the power output of a fuel-cell stack, the greater is the heat generation. The materials of construction are temperature sensitive; thus, the cell temperature must be carefully controlled. The cells are also more compact than other types of fuel cells, leading to higher power densities and higher heat rejection rates per unit volume. Unlike alkaline cells, which have a liquid electrolyte that can be circulated to heat exchangers and easily cooled, cooling of stacks of polymer electrolyte fuel cells will be more complex. Because the expected market is for vehicle fuel cells with relatively small power outputs [10-300 kW(e)], methods to cool large high-power fuel cells have not been seriously investigated.

- Corrosion. Pure oxygen is more corrosive than air. Based on the mixed evidence, it is unclear whether this is a major design constraint with these specific fuel cells and the associated materials of construction.

These fuel cells may be manufactured in very large quantities to obtain low manufacturing costs; thus, they are serious contenders for use in PENS. They may be particularly attractive for variants of PENS that use distributed hydrogen (Sect. 4.4).

\subsubsection{Molten carbonate fuel cells}

Molten carbonate fuel cells (Fig. 4.5) are being developed for natural gas and coal-based power plants for industrial and utility applications. These fuel cells can operate with "dirty fuels" (unlike other types of fuel cells) and require carbon dioxide. (Many other fuel cells cannot operate with high concentrations of carbon dioxide.) Recent reviews have summarized the status of this technology (EG\&G Technical Services 2002).

These fuel cells have a five-layer structure: gas channels for hydrogen feed; an anode membrane; a zone containing molten carbonates, typically a mixture of lithium carbonate and potassium carbonate; a cathode membrane; and gas channels for air or oxygen feed. Unlike other fuel cells, the membranes are porous with very small channels and use capillary pressure to prevent leakage of the carbonate. Traditional molten carbonate fuel cells use air as an oxidizer. The overall chemical reactions are as follows:

Anode reaction

Cathode reaction

Overall cell reaction

$$
\begin{aligned}
& \mathrm{H}_{2}+\mathrm{CO}_{3} \rightarrow \mathrm{H}_{2} \mathrm{O}+\mathrm{CO}_{2}+2 \mathrm{e}^{-} \\
& 1 / 2 \mathrm{O}_{2}+\mathrm{CO}_{2}+2 \mathrm{e}^{-} \rightarrow \mathrm{CO}_{3}= \\
& \mathrm{H}_{2}+1 / 2 \mathrm{O}_{2}+\mathrm{CO}_{2} \text { (cathode) } \rightarrow \mathrm{H}_{2} \mathrm{O}+\mathrm{CO}_{2} \text { (anode) }+ \text { electricity }+ \text { heat }
\end{aligned}
$$




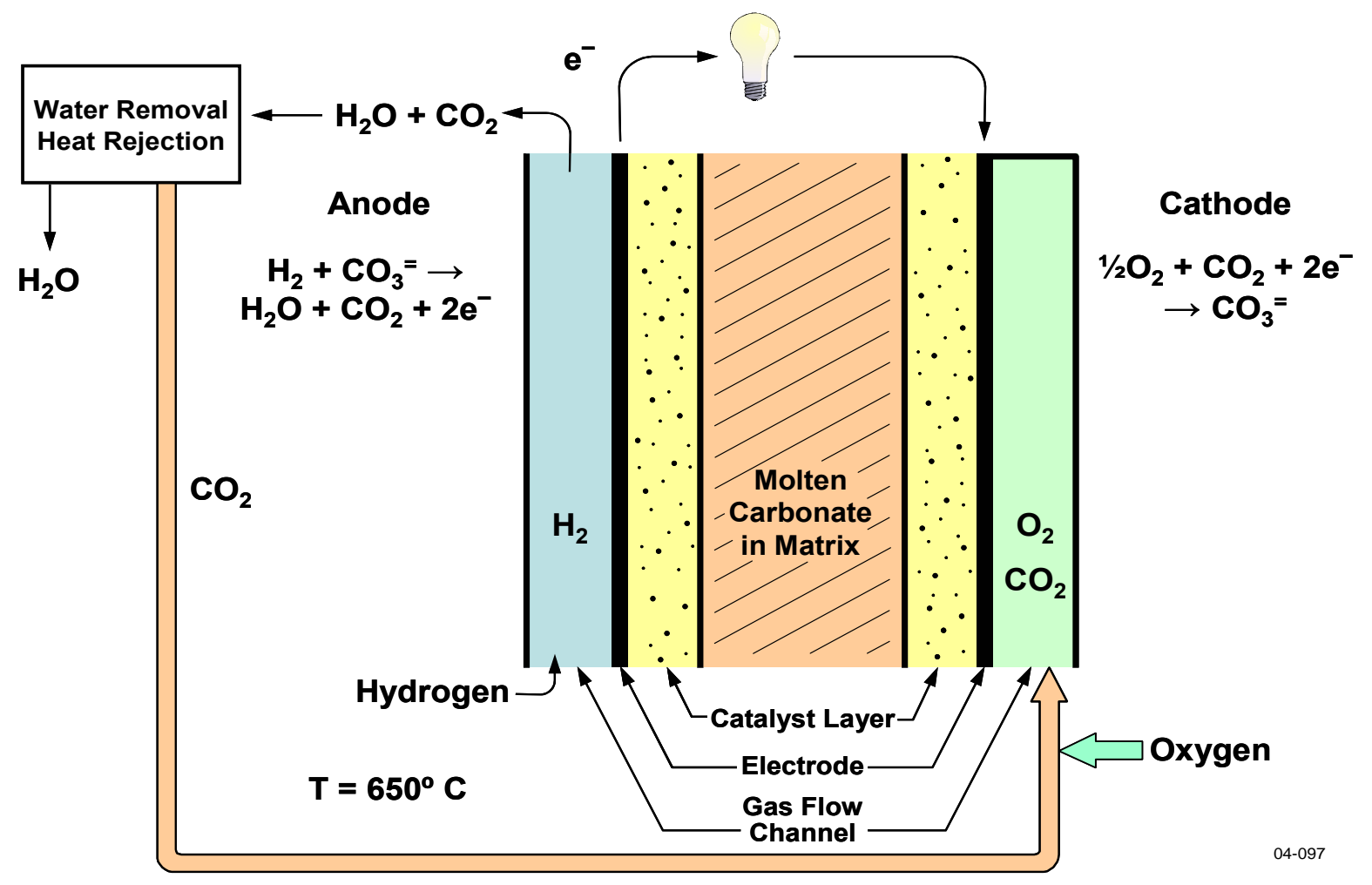

Fig. 4.5. Molten carbonate fuel cell.

Molten carbonate fuel cells typically operate near $650^{\circ} \mathrm{C}$. The high operating temperature is required to maintain sufficient conductivity of the carbonate electrolyte. Higher temperatures are avoided to minimize the need for more expensive high-temperature materials of construction. What is significantly different about molten carbonates is the requirement for a carbon dioxide management system to ensure high carbon dioxide concentrations with the oxygen.

These fuel cells are being developed for industrial applications and can be built in large sizes. The high temperatures avoid the need for noble metal catalysts. Using oxygen, rather than air, would be expected to significantly increase the power output of a given fuel cell, improve efficiency, and lower costs. Although there are the traditional gains associated with replacing air with oxygen, other gains are specific to this type of fuel cell. In existing molten carbonate fuel cells, there is the problem of how to recycle carbon dioxide from the anode (hydrogen side) to the cathode (air side). For this type of fuel cell to operate, carbon dioxide must be present with the oxygen. When air is used as the oxidizer, carbon dioxide must be added to create the proper mixture of oxygen and carbon dioxide, which produces a mixture of oxygen, carbon dioxide, and nitrogen. Because air is $80 \%$ nitrogen, the primary gas component of the mixture is nitrogen. However, only a fraction of the carbon dioxide and oxygen is 
consumed as they pass through the fuel cell and what emerges is nitrogen with oxygen and carbon dioxide. While the air has a low cost (except for pumping power), the carbon dioxide represents a significant cost in terms of the energy and capital required to separate and recover it from the other gases for recycle to the fuel cell. If oxygen is used rather than air, a mixture of one-third oxygen and two-thirds carbon dioxide is fed to the cathode. This mixture is fully utilized, thus maximizing the performance of the cathode. Equally important, none of the carbon dioxide is emitted to the atmosphere, because no loss of carbon dioxide occurs in the system. The system contains no nitrogen that must be dumped from the fuel cell, and the carbon dioxide from the anode is the source of carbon dioxide for the cathode. The use of oxygen results in major simplifications in this type of fuel cell.

\subsubsection{High-temperature solid-oxide fuel cells}

Solid-oxide fuel cells (SOFCs), which are being developed to produce electricity and heat for industrial and commercial applications (Hoogers 2003; Larminie and Dicks 2000; EG\&G Technical Services 2002), represent a potential replacement for gas turbines. SOFCs (Fig. 4.6) operate at high temperatures $\left(600-1000^{\circ} \mathrm{C}\right)$, which avoids the need for expensive catalysts. Current efficiencies are between 50 and $60 \%$. However, their high-temperature operation limits their potential use in vehicles.

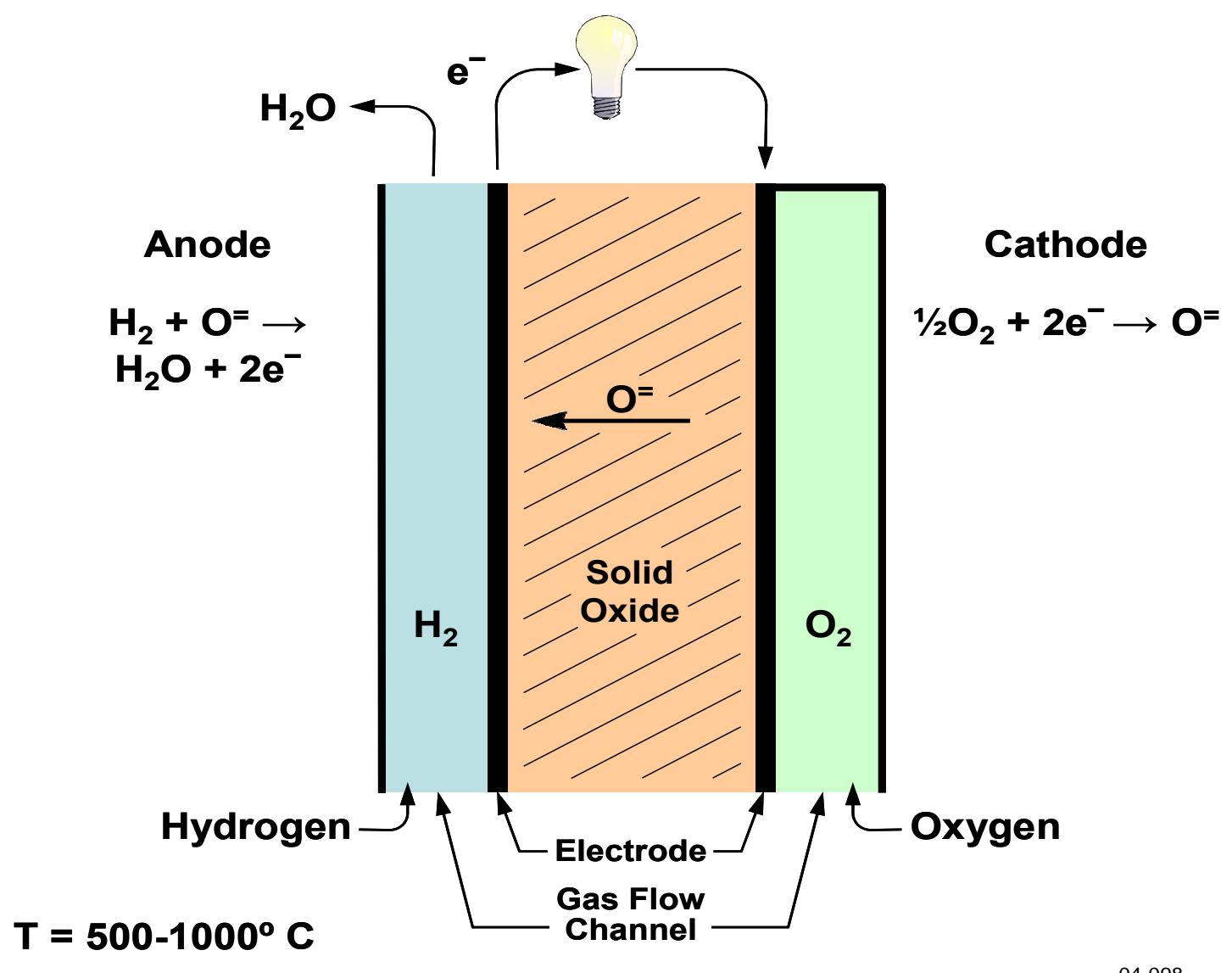

Fig. 4.6. Solid-oxide fuel cell. 
The fuel cells have a multilayer structure: gas-flow channels for the hydrogen feed, an anode, a solid oxide, a cathode layer, and flow channels for the air feed. The overall chemical reactions are as follows:

$$
\begin{array}{ll}
\text { Anode reaction } & \mathrm{H}_{2}+\mathrm{O}^{=} \rightarrow \mathrm{H}_{2} \mathrm{O}+2 \mathrm{e}^{-} \\
\text {Cathode reaction } & 1 / 2 \mathrm{O}_{2}+2 \mathrm{e}^{-} \rightarrow \mathrm{O}^{=} \\
\text {Overall cell reaction } & \mathrm{H}_{2}+1 / 2 \mathrm{O}_{2} \rightarrow \mathrm{H}_{2} \mathrm{O}+\text { electricity }+ \text { heat }
\end{array}
$$

Unlike other fuel cells, oxygen diffuses through the oxide layer, typically a yttrium-stabilized zirconium oxide membrane. The high temperatures are required for commercially viable rates of oxygen diffusion through the membrane.

The performance of single-cell SOFCs is significantly increased by using pure oxygen rather than air. If pure oxygen is used, the driving force for oxygen diffusion across the oxide layer increases by a factor of 5, which implies a large increase in output. However, there are uncertainties about the scale of gains in terms of system performance with the use of oxygen. Like all fuel cells, the SOFC generates excess heat. Currently, the excess heat is removed from the SOFC by blowing excess air through the fuel-cell stack. If oxygen is used, the rate of gas flow must be significantly increased to remove the additional heat. The flow channels are small, and the heat capacity of oxygen is relatively low; thus, significant pumping costs are incurred to circulate the oxygen between the fuel cell and an external heat exchanger. A second issue is how efficiently SOFCs could be cycled off and on. The high-temperature operation implies that thermal transients are a major operational and design constraint.

\subsubsection{Phosphoric acid fuel cells}

The phosphoric acid fuel cell (Fig. 4.7) was the first type to be commercialized. The largest plant operated to date had an output of $11 \mathrm{MW}(\mathrm{e})$. The development is for industrial (nonvehicle) applications with air as the oxidizer. Recent reviews have summarized the status of this technology (EG\&G Technical Services 2002).

These fuel cells have a five-layer structure: gas channels for hydrogen feed, an anode membrane, phosphoric acid in a matrix, a cathode membrane, and gas channels for air/oxygen feed. Traditional phosphoric acid fuel cells are fed hydrogen and air. The overall chemical reactions are as follows:

$$
\begin{array}{ll}
\text { Anode reaction } & \mathrm{H}_{2} \rightarrow 2 \mathrm{H}^{+}+2 \mathrm{e}^{-} \\
\text {Cathode reaction } & 1 / 2 \mathrm{O}_{2}+2 \mathrm{H}^{+}+2 \mathrm{e}^{-} \rightarrow \mathrm{H}_{2} \mathrm{O} \\
\text { Overall cell reaction } & \mathrm{H}_{2}+1 / 2 \mathrm{O}_{2} \rightarrow \mathrm{H}_{2} \mathrm{O}+\text { electricity }+ \text { heat }
\end{array}
$$

Phosphoric fuel cells typically operate at temperatures near $200^{\circ} \mathrm{C}$ and at acid concentrations of $\sim 100 \%$ phosphoric acid. The fuel cell may be operated at atmospheric or higher pressures.

From an industrial perspective today, these fuel cells have several attractive features. They are tolerant of carbon dioxide in the hydrogen stream that results from the reforming of liquid fuels into hydrogen, and they can also accommodate the carbon dioxide in air. Phosphoric acid fuel cells are being developed for industrial applications and can be built in large sizes. Data indicate that the power output can be increased by a factor of 3 when replacing air as an oxidizer with oxygen. However, the fuel cells require expensive noble metals as catalysts and, with current materials, internal corrosion problems become much more severe when the fuel cell is in a hot idle mode. In a PENS facility, the fuel cells will be in a hot idle mode much of the time. The efficiency (using air and reforming of natural gas) is 37 to $42 \%$, based on the lower heating value of natural gas. This percentage is at low end of efficiencies for fuel cells. In many industrial applications, the reject heat can be used for other purposes; however, this is unlikely to be a realistic option for PENS. The performance of phosphoric acid fuel cells using pure oxygen and hydrogen must still be assessed. 


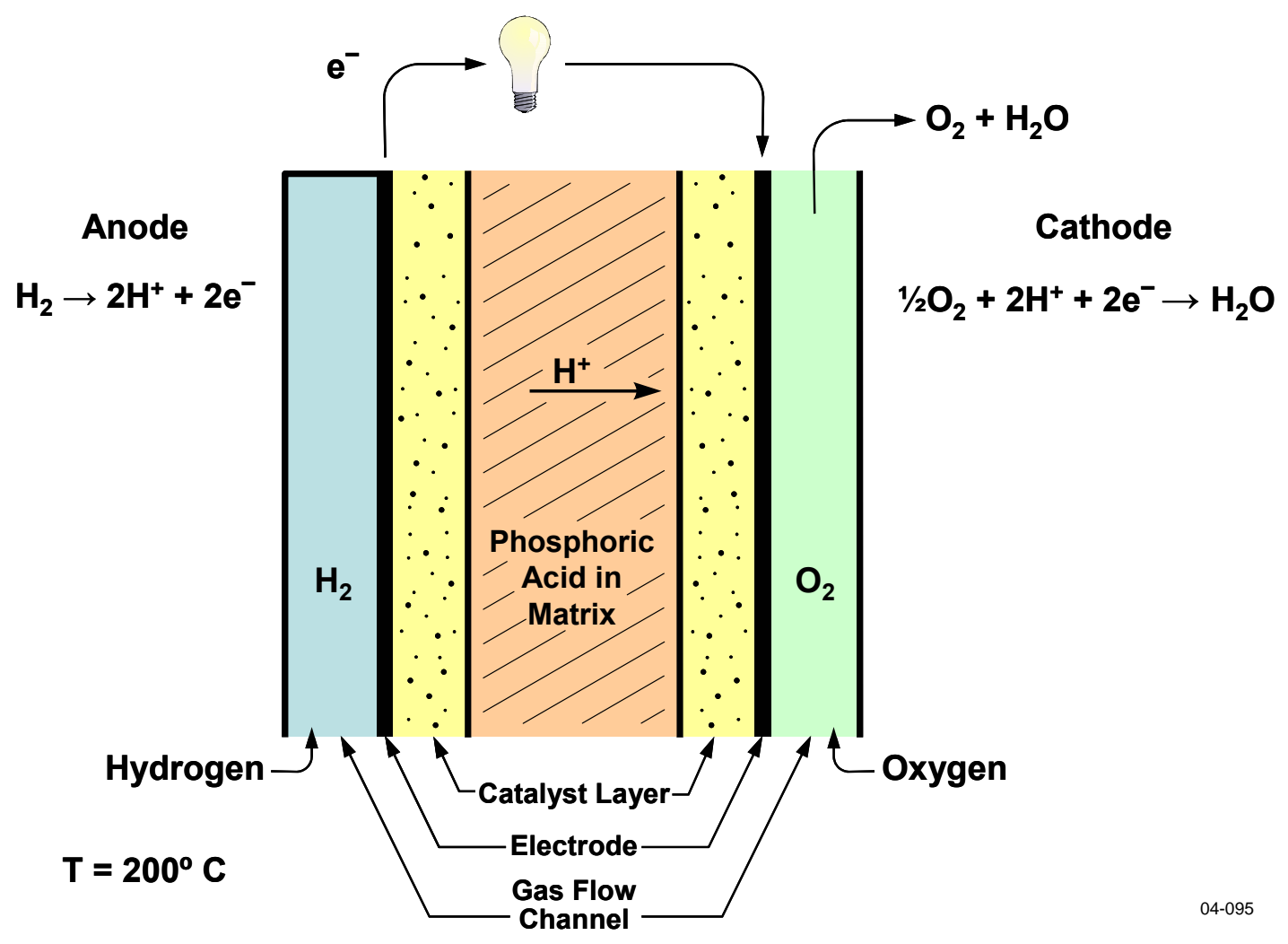

Fig. 4.7. Phosphoric acid fuel cell.

\subsubsection{Fuel-Cell Economics}

Traditional fuel-cell applications produce kilowatts or for a few megawatts of energy. The application described in this report is for hundreds or thousands of megawatts of power when oxygen feed is used. No studies of the costs of large-scale fuel-cell facilities have been undertaken. However, three economic factors have been identified that will alter the fuel-cell economics relative to other applications.

- Oxygen feed. Pure oxygen feed (rather than air) will significantly improve efficiency and reduce the capital costs of the fuel-cell component of the system by factor of 2 or 3 per kilowatt (electrical).

- Manufacturing economics. A large fuel-cell complex allows efficiencies in the manufacture of specific components such as the fuel-cell stacks. 
- Economics of scale. Large economics of scale are associated with buildings, electrical conversion equipment, and gas-handling systems (compressors, pipes, valves, etc.). In this specific case, some understanding of the potential economics of scale is obtained by examining large chlorine production facilities. Chlorine, which is used for water treatment, is produced on a massive scale. In a chlorine production facility, electricity is used to convert a brine solution to chlorine and sodium hydroxide. The facility includes large electrolytic cells, gas-handling systems for toxic gases, and electrical power conversion systems. The scaling factor (Goosseng et al. 2003) for chlorine plants has been estimated at 0.54; that is, increasing the size of the facility by a factor of 4 results in the capital cost of the larger facility being only $53 \%$ of that of the smaller facility per unit of capacity. Very large economics of scale exist in such a process. A large alkaline fuel-cell facility has many similarities to a chlorine plant [electrolytic cell, hazardous gas processing (oxygen rather than chlorine), liquid hydroxide processing systems with heat removal, etc.] that may enable relatively good estimates of the performance of PENS with alkaline fuel cells.

\subsection{ELECTRICAL TRANSMISSION}

The economics of hydrogen production, hydrogen storage, and fuel cells support large-scale centralized facilities. However, the economics of the electrical transmission system favor smaller systems to reduce the size of the electrical grid. The option does exist to have a centralized hydrogen production and storage facility with several large fuel-cell complexes to reduce the electrical transmission grid requirements (Fig. 4.8). To minimize the size of the hydrogen pipeline system, the fuel-cell complexes would be located near major transmission lines entering large metropolitan areas. At times of peak electrical demand, electricity would be inputted into the grid both to flow to the large metropolitan areas and to provide peak electricity to other markets. Analysis of transmission grid constraints is required to develop siting strategies for such facilities.

This type of system would reduce the electrical transmission infrastructure. However, analysis is required to determine if it is viable to transport oxygen over moderate distances to such fuel-cell complexes. The issue is safety, not economics. The option does exist to heat the oxygen (see Sect. 4.2); however, significant cooling of oxygen will occur during transport. 


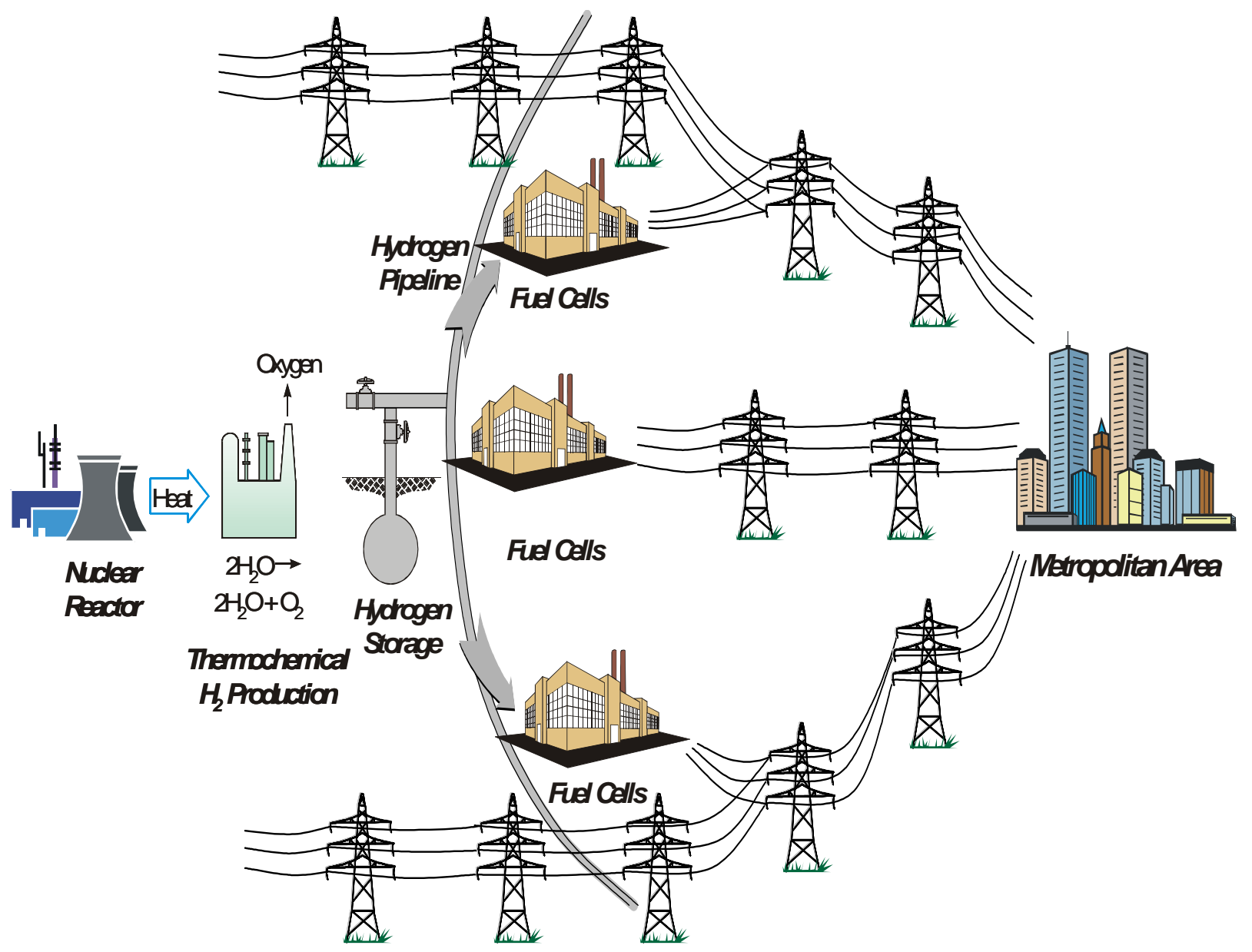

Fig. 4.8. PENS with multiple fuel-cell complexes. 


\section{SYSTEM ECONOMICS}

Insufficient information has yet been collected to fully understand the economics. The data collected at present indicate that an economic PENS is possible — based on the projected costs of nuclear hydrogen and the potential that fuel cells will be significantly less expensive than gas turbines, particularly with oxygen feed (Fig. 5.1).

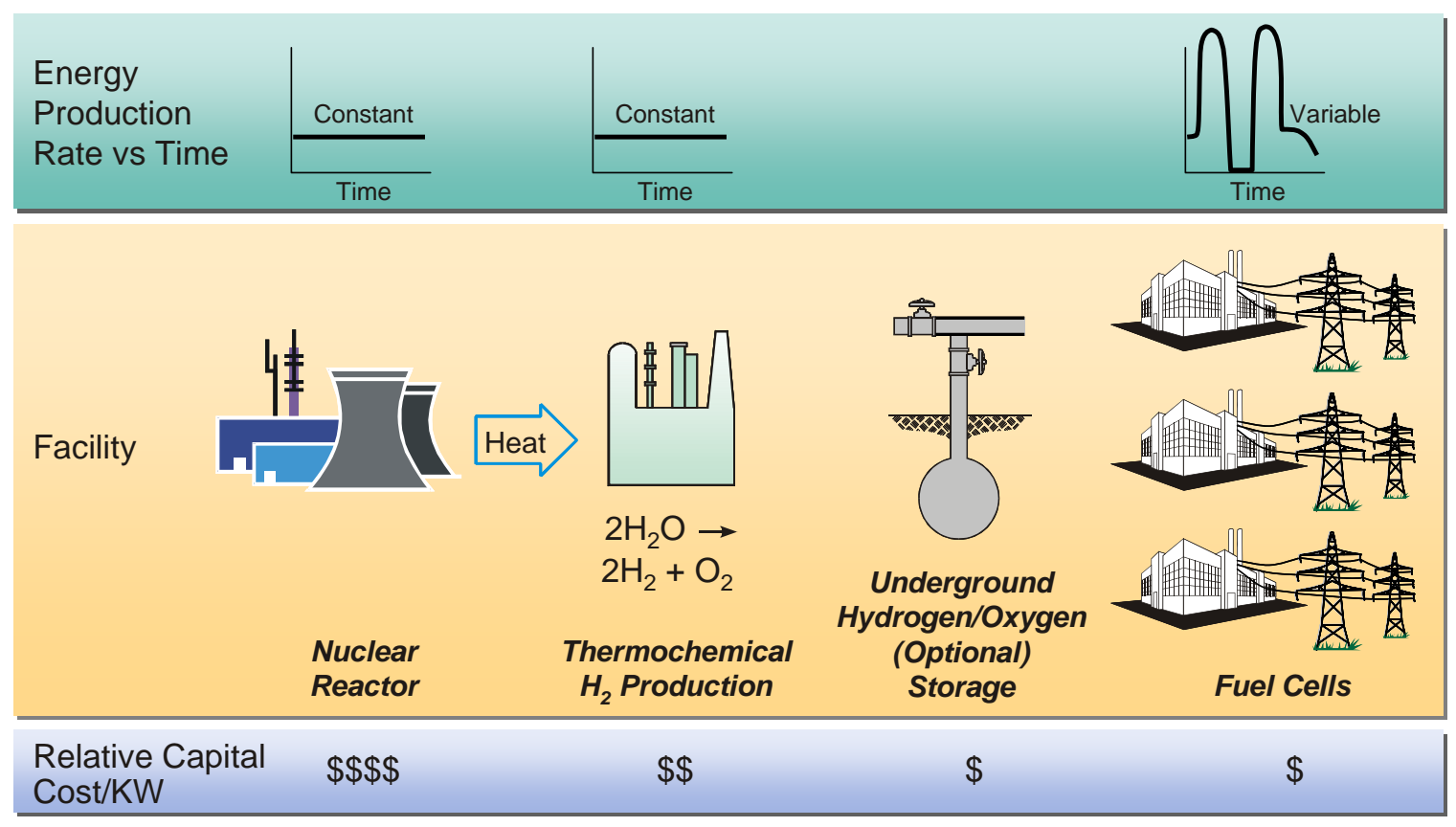

Fig. 5.1. Relationship of PENS economics to production of electricity for periods of high demand.

The capital costs for nuclear hydrogen plants are projected to exceed $\$ 1000 / \mathrm{kW}(\mathrm{e})$ equivalent in hydrogen. The capital costs for hydrogen storage are \$200-400 million/GW-year. The goal (U.S. Department of Energy 2002) of fuel-cell developers is to reduce the capital cost for hydrogen fuel cells to $<\$ 50 / \mathrm{kW}(\mathrm{e})$ with efficiencies of $\sim 70 \%$, compared with $\sim \$ 500 / \mathrm{kW}(\mathrm{e})$ for gas-turbine plants with efficiencies of $\sim 50 \%$. PENS fuel cells will have a lower cost per kilowatt (electrical) than fuel cells used in other applications because of (1) the economies of scale associated with the large fuel-cell facilities;

(2) the use of a feed of pure hydrogen (not natural gas or hydrogen from steam reforming, both of which have various impurities); and (3) the use of pure oxygen, rather than air. An important caveat should be noted. While the costs of gas turbines are based on operational experience, those for fuel cells are based on projections. 
Some perspective on the capital-cost drivers of PENS can be derived by an example that estimates capital costs per kilowatt (electrical) of peak electric power that is produced. The example in Table 5.1 should not be considered a definitive capital cost estimate. Significant additional work is required before a realistic capital cost estimate can be made (see Sect. 7). The example assumes that the peak electrical power output is six times that of the nuclear reactor and that sufficient hydrogen is stored for one month of operation without operation of the hydrogen production plant. This covers the annual the nuclear plant refueling outage.

Table 5.1. Example Capital Cost Estimate for PENS ${ }^{a}$

\begin{tabular}{|c|c|c|}
\hline Facility & Cost Calculation & $\begin{array}{c}\text { Capital Cost } \\
\$ / \mathbf{k W}(\mathbf{e})_{\text {peak }}\end{array}$ \\
\hline Hydrogen Plant & {$[\$ 1000 / \mathrm{kW}(\mathrm{e}-$ equivalent $)](1 / 6)(1 / 0.7)$} & 238 \\
\hline Hydrogen Storage & $(\$ 300 / \mathrm{kw}-\mathrm{y})(1 \mathrm{y} / 12$ months $)(1 / 6)$ & 4 \\
\hline Fuel Cells & 50 & 50 \\
\hline Total & & 292 \\
\hline
\end{tabular}

${ }^{a}$ Assumptions: Fuel cell efficiency 0.7 ; fuel cell capital cost $\$ 50 / \mathrm{kW}(\mathrm{e})$; hydrogen storage cost: $\$ 300 / \mathrm{kw}-\mathrm{y}$; nuclear hydrogen plant costs: $\$ 1000 / \mathrm{kW}(\mathrm{e})$ hydrogen equivalent; $6 \mathrm{~kW}(\mathrm{e})$ peak power per $\mathrm{kW}(\mathrm{e})$ of hydrogen plant.

This example is highly simplified; but, several conclusions can be drawn.

- Capital cost drivers. The cost of the nuclear hydrogen production plant and the fuel cells drive the total system capital costs.

- Hydrogen storage costs. Hydrogen storage costs are not a major cost driver.

- Peak power output. A critical factor is the ratio of peak electric output to the output of the reactor. Assuming low cost fuel cells, the higher this ratio, the lower the total capital costs per kilowatt (electrical) peak power output.

Total costs depend upon both the capital costs and the operating costs. The operating costs of PENS are very low compared to a gas turbine because of the low costs for nuclear fuel compared to natural gas. The relative economics of PENS compared to gas turbines depends upon (1) the capital costs of individual components, (2) the relative operating costs, and (3) the demand for peak and intermediate electric power (ratio of peak power output to reactor output). 


\section{OTHER CONSIDERATIONS}

If implemented, PENS has several other implications. A major issue for the hydrogen economy is how to make the transition from the existing liquid-fuel infrastructure to a hydrogen infrastructure. The chickenand-egg problem is that large-scale hydrogen production is needed for low-cost hydrogen. However, large-scale production will not occur until a large-scale market exists. PENS avoids this constraint. It provides a massive market for hydrogen, with the option of the utility to produce hydrogen for sale, in addition to operation of the fuel-cell complex. When this occurs, the lower-capital-cost fuel-cell system is not operated. However, the capital-intensive components of the system (the reactor and thermochemical hydrogen production plant) always operate at full capacity. The continuing market for hydrogen to produce electricity using the fuel-cell production system ensures full reactor and thermochemical plant utilization.

PENS has other major implications for development of a hydrogen economy. The system implies the deployment of large-scale hydrogen storage facilities and fuel-cell complexes. These developments will lay the technical, institutional, and economic foundations for the more widespread use of hydrogen.

Last, PENS may have a major impact on electrical grid management. Grid reliability, which has become a major issue, is strongly dependent upon available spinning reserve. Fuel cells have the unusual technical characteristic of being able to go from no load to high power levels almost instantaneously. While clearly advantageous, the full implications of this type of spinning reserve on grid reliability and the quality of electric power are not well understood. 


\section{REQUIRED SYSTEMS R\&D}

This report provides an initial description of PENS. The initial assessment indicates that PENS is a potential first market for nuclear hydrogen. However, major uncertainties remain. Systems $R \& D$ is required to meet the top-level goal of understanding the economics, what controls the economics, and whether PENS should be used as part of the basis for commercialization of a nuclear hydrogen system. Some of the required information has been collected, but much remains to be done. An economic systems model of PENS is required, which requires several types of input:

- Existing systems. Many components of the system already exist (markets, underground storage caverns, and electrical transmission grids) and are well understood. In these areas, existing information must be collected, analyzed, and inputted into a model of PENS.

- New systems. In several areas, technical analysis is required to understand performance of specific components. Understanding the technical performance provides the input to understand the economics. Examples include the heating required to ensure safe storage of oxygen and the performance of various types of fuel cells when they are fed oxygen versus air (the traditional oxidizer).

- Parametric inputs. Several system components, such as fuel cells, are under development. The costs of these must be parametrically evaluated to determine when PENS is economically competitive. In most of these areas, information on the projected costs over time is available. However, these data has to be adjusted for the different technical characteristics of PENS. For example, the DOE Office of Energy Efficiency and Renewable Energy (DOE/EE) has performed multiple evaluations of fuel cells using air. For PENS, the analysis must adjust the information to account for oxygen feed rather than air.

- Optimization. The economics of PENS depend upon meeting peak electrical demand and spinning reserve requirements. Modeling must be performed to understand the system characteristics of PENS that determine critical engineering features such as the power output of the fuel-cell banks relative to the energy output of the reactor. For example, should the fuel-cell facility have 2, 4, or 8 times the equivalent electric output [kilowatts (electrical)] of the reactor? These questions have major impacts on the economics and the viability of PENS.

R\&D must be done in cooperation with the utility industry to provide credible results. Preliminary discussions have been undertaken with TVA and the Electric Power Research Institute (EPRI). TVA is a large government-owned utility that owns and operates the Raccoon Mountain Pumped Storage Plant. Pumped storage facilities have many of the same functional characteristics as PENS; thus, the understanding of pumped storage operations and their economics can be used to understand the market requirements for PENS. EPRI, which was created by the electric utilities in the United States to address common R\&D requirements, has a variety of studies under way that address the problem of meeting peak and intermediate electrical demand. Also continuing are large ongoing activities associated with the development of fuel cells and hydrogen storage, areas in which close cooperation between different organizations is required. 


\section{CONCLUSIONS}

Based on analysis and information collected to date, PENS may provide a large-scale, early market for nuclear hydrogen. However, many uncertainties remain. Systems studies are required to quantify the economics. If this analysis confirms the initial assessments, PENS becomes the logical early market for nuclear hydrogen and PENS should be used as part of the planning basis for the development of a nuclear hydrogen system. System analysis of PENS will help define (1) the industrial partners for commercialization of nuclear hydrogen technologies, (2) the technical requirements for nuclear hydrogen facilities, and (3) the required production costs for nuclear hydrogen to be economically viable- based on the peak- and intermediate-load electrical prices. The next steps involve (1) collecting and analyzing missing information, including projected life-cycle costs, and (2) working with utility, fuel cell, industrial gas, and other industrial organizations to validate the information. 


\section{REFERENCES}

EG\&G Technical Services, Inc., and Science Applications International Corporation, 2002, Fuel Cell Handbook (Sixth Edition), DOE/NETL-2002/1179, U.S. Department of Energy,

Morgantown, West Virginia (November).

Ernst, W. and J. Nerschook, 2004, “Telecoms Networks: The New Rules of Power,” The Fuel Cell Review, pp. 25-28 (June/July).

Farbman, G. H., 1976, The Conceptual Design of an Integrated Nuclear Hydrogen Production Plant Using the Sulfur Cycle Water Decomposition System, NASA-CR-134976, Westinghouse Electric Corporation, Pittsburgh, Pennsylvania (April).

Goosseng, J. E., E. J. Lahoda, R. A. Matzie, and J. P. Mazzoccoli, 2003, "Improvements in the Westinghouse Process for Hydrogen Production," in Global 2003, Embedded Topical Within 2003 American Nuclear Society Winter Meeting, November 16-20, 2003, New Orleans, Louisiana.

Hoogers, G. (ed.), 2003, Fuel Cell Technology Handbook, CRC Press, Boca Raton, Florida.

Larminie, J. and A. Dicks, 2000, Fuel Cell Systems Explained, Wiley, New York.

McLean, G. F., T. Niet, S. Prince-Richard, and N. Djilal, 2002, "An Assessment of Alkaline Fuel Cell Technology," Int. J. Hydrogen Energy, 27, 507-526.

Miller, A. I. and R. B. Duffy, 2003, "Hydrogen from Nuclear Energy and the Potential Impact on Climate Change," in Proc. OECD/NEA Second Information Exchange Meeting on Nuclear Production of Hydrogen, October 2-3, 2003, Argonne National Laboratory, Argonne, Illinois, Nuclear Energy Agency, Paris.

Shiozawa, S., et al., 2000, "Present Status of JAERI's R\&D on Hydrogen Production Systems in HTGR," in Nuclear Production of Hydrogen: First Information Exchange Meeting, Paris, France, October 2-3, 2000, OECD/NEA, Paris.

Thompson, J. M., 1997, "U.S. Underground Storage of Natural Gas in 1997: Existing and Proposed," Natural Gas Monthly, United States Energy Information Administration (September).

U.S. Department of Energy, 2002, National Hydrogen Energy Roadmap, Washington, D.C. (November).

U.S. Department of Energy, 2003, Nuclear Hydrogen Initiative Research and Development Plan, Office of Nuclear Energy, Washington, D.C.

U.S. Energy Information Agency, 1995, The Value of Underground Storage in Today's Natural Gas Industry, DOE/EIA-0591(95), Washington, D.C. (March).

U.S. National Research Council, 2004. The Hydrogen Economy: Opportunities, Costs, Barriers, and $R \& D$ Needs, National Academy Press, Washington D.C. 

ORNL/TM-2004/104

\section{INTERNAL DISTRIBUTION}

1. T. R. Armstrong (armstrongt@ornl.gov)

2. S. J. Ball (ballsj@ornl.gov)

3. J. L. Binder (binderil@ornl.gov)

4. W. R. Corwin (corwinwr@ornl.gov)

5. C. W. Forsberg (forsbergcw@ornl.gov)

6. S. R. Greene (greenesr@ornl.gov)

7. R. A. Hawsey (hawseyra@ornl.gov)

8. D. J. Hill (hilldj@ornl.gov)

9. R. F. Holdaway (holdawayrf@ornl.gov)

10. D. T. Ingersoll (ingersolldt@ornl.gov)

11. Brenden Kirby (kirbybj@,ornl.gov)

12. John Kueck (kueckjd@ornl.gov)

13. G. E. Kulynych (kulynychge@ornl.gov)
14. P. N. Leiby (leibypn@ornl.gov)

15. G. T. Mays (maysgt@ornl.gov)

16. G. E. Michaels (michaelsge@ornl.gov)

17. D. L. Moses (mosesdl@ornl.gov)

18. C. V. Parks (parkscv@ornl.gov)

19. C. D. Ringer (ringercd@y12.doe.gov)

20. J. E. Rushton (rushtonje@ornl.gov)

21. J. J. Simpson (simpsonjj@ornl.gov)

22. D. F. Williams (williamsdf2@ornl.gov)

23. ORNL Central Research Library (conradre@ornl.gov)

24. ORNL Laboratory Records-RC (hamrindr@ornl.gov)

\section{EXTERNAL DISTRIBUTION}

25. H. E. Clark, U.S. Department of Energy/Oak Ridge Field Office, Oak Ridge, TN 37831 [clarkhe@ornl.gov]

26. R. D. Doctor, Argonne National Laboratory, 9700 S. Cass Ave., Argonne, IL 60439-4815 [rdoctor@anl.gov]

27. A. David Henderson, U.S. Department of Energy, Office of Nuclear Energy, Science and Technology (NE-20), 19901 Germantown Rd., Germantown, MD 20874-1290 [david.henderson@,nuclear.energy.gov]

28. R. S. Johnson, U.S. Department of Energy, NE-24, Germantown Building, 1000 Independence Ave., SW, Washington, D.C. 20585 [shane.johnson@hq.doe.gov]

29. J. H. Kolts, Idaho National Engineering and Environmental Laboratory, Mailstop 3860, 2525 N. Fremont Ave., P.O. Box 1625, Idaho Falls, ID 83415 [koltjh@inel.gov]

30. P. E. MacDonald, Idaho National Engineering and Environmental Laboratory, Mailstop 3870, 2525 N. Fremont Avenue, P. O. Box 1625, Idaho Falls, ID 83415 [pem@inel.gov]

31. W. D. Magwood, U.S. Department of Energy, NE-1, 1000 Independence Ave., SW, Washington, DC 20585 [william.magwood@hq.doe.gov]

32. S. R. Martin, Jr., U.S. Department of Energy, Oak Ridge Field Office, Oak Ridge, TN 37831 [martinsrjr@ornl.gov]

33. M. D. Paster, U.S. Department of Energy, EE-2H/Forestall Building, 1000 Independence Ave., SW, Washington, DC 20585 [mark.paster@hq.doe.gov]

34. P. F. Peterson, University of California, Berkeley, Nuclear Engineering Department, 4153 Etcheverry Hall, Berkeley, CA 94720-1730 [peterson@nuc.berkeley.edu]

35. M. C. Petri, Argonne National Laboratory, 9700 S. Case Ave., Argonne, IL 60439-4815 [mcpetri@anl.gov]

36. P. S. Pickard, Sandia National Laboratories, P. O. Box 5800, Albuquerque, NM 87185-1136 [pspicka@sandia.gov] 
37. C. J. Sink, Jr., U.S. Department of Energy, NE-20, Germantown Building, 1000 Independence Ave., SW, Washington, DC 20585 [carl.sink@em.doe.gov]

38. A. C. Taylor, U.S. Department of Energy, NE-40/Germantown Building, 1000 Independence Ave., SW, Washington, DC 20585-1290 [amy.taylor@hq.doe.gov]

39. R. M. Versluis, U.S. Department of Energy, NE-20/Germantown Building, 1000

Independence Ave., SW, Washington, DC 20585-1290 [rob.versluis@hq.doe.gov] 